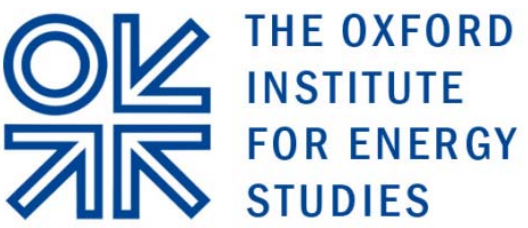

\title{
The Implications of the Arab Uprisings for Oil and Gas Markets
}

\author{
Hakim Darbouche \\ $\&$ \\ Bassam Fattouh*
}

September 2011

MEP 2

\footnotetext{
* The authors thank for their comments Robert Mabro, Christopher Allsopp, Laura El-Katiri, Jonathan Stern and Mostefa Ouki. Any mistakes, in fact or interpretation, remain their own.
} 
The contents of this paper are the authors' sole responsibility. They do not necessarily represent the views of the Oxford Institute for Energy Studies or any of its members.

Copyright (c) 2011

\section{Oxford Institute for Energy Studies}

(Registered Charity, No. 286084)

This publication may be reproduced in part for educational or non-profit purposes without special permission from the copyright holder, provided acknowledgment of the source is made. No use of this publication may be made for resale or for any other commercial purpose whatsoever without prior permission in writing from the Oxford Institute for Energy Studies.

ISBN

978-1-907555-33-6 


\section{Contents}

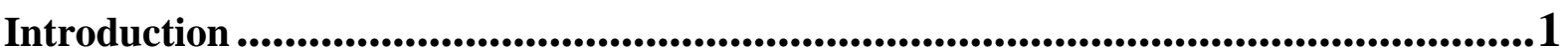

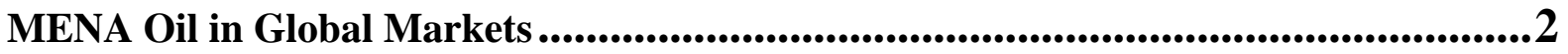

Security of MENA Oil Supplies....................................................................................

The Immediate Impact of the Arab Uprisings on Oil Markets ………………………............

The Long-Term Impact of the Arab Uprisings on Oil Markets ............................................13

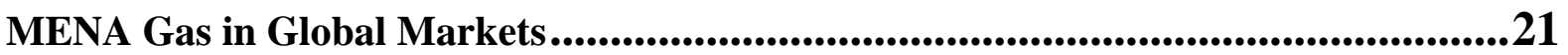

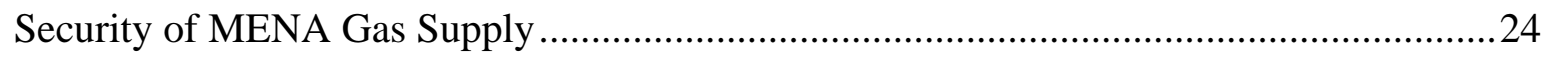

The Immediate Impact of the Arab Uprisings on MENA Gas Supply …..............................27

Likely Long-Term Implications for Gas Policy ……………………………………............34

Conclusion - main messages ..........................................................................................39

\section{Tables}

Table 1: Some Basic Facts about MENA Oil ...................................................................2

Table 2: Significant Middle East and North African Oil Crises, 1950-2011 ..........................4

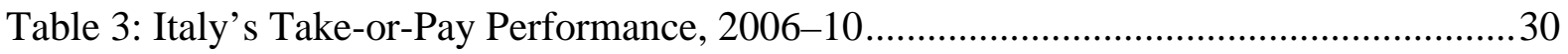

\section{Figures}

Figure 1: Year-on-Year Change in Global Oil Consumption 2000-10 (mb/d) ........................ 8

Figure 2: OPEC Total Spare Crude Oil Production Capacity 2000-10 (mb/d).......................8

Figure 3: Europe Brent Spot Price FOB January 2009- April 2011 (\$/Barrel).......................10

Figure 4: Key Middle East Events and the Oil Price October 2010-April 2011....................11

Figure 5: Brent-Dubai Price Differential January-August 2011 (US\$/Barrel)......................12

Figure 6: Brent Term Structure: First month-Second month ............................................12

Figure 7: Bonny Light-Dated Brent Price Differential January-May 2011 (\$/Barrel)...........13 
Figure 8: The Impact of Disruptions on Productive Capacity ..............................................14

Figure 10: MENA’s Share of Global Oil Consumption 1980-2010 .....................................17

Figure 11: Total Primary Energy Consumption per Dollar of GDP 1980-2008 (Btu per Year

2005 U.S. Dollars (Purchasing Power Parities))..................................................................17

Figure 12: Oil Price Needed to Balance Budget in Saudi Arabia 2003-2012........................19

Figure 13: Brent-Dubai Price Differential June-August 2011 (US\$/Barrel).........................20

Figure 14: MENA vs. World Gas Production, 1999-2010 ....................................................22

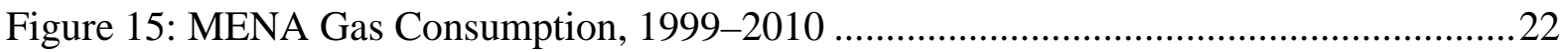

Figure 16: MENA vs. World Gas Pipeline Exports, 1999-2010 ..........................................23

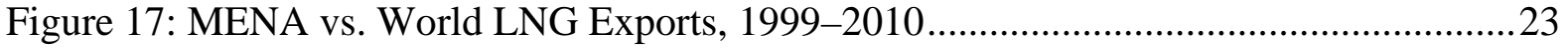

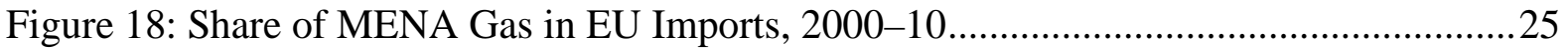

Figure 19: European Spot Gas Prices February-March 2011 (\$/MMBtu) ..............................31

Figure 20: Impact of the Transitgas and Greenstream Shutdowns on PSV Prices ..................31

Figure 21: Italian Gas Imports by Source, First Half 2010 vs. First Half 2011......................32

Figure 22: Average Wholesale Gas Prices by Region in 2009 (\$/MMBtu) ............................35 


\section{Introduction}

The events that took place in the Arab world in the opening months of 2011 mark a watershed in the history of the Middle East and North Africa (MENA) region. Spontaneous, grass-roots coalitions of mostly young people, united by shared grievances and helped by new means of civic organization, have succeeded where traditional opposition movements had hitherto failed. They have carved out a new sense of political agency for the oppressed majority, and in doing so have forced long-serving despots out of office and have challenged longstanding external assumptions about the philosophy and practice of politics in the Arab world. However, much as they have shaken the existing socio-political order in the region, the final outcome of the recent events is as yet unknown and the longer-term consequences of the transformation process they appear to have set in motion are highly uncertain.

Given the importance of MENA energy supplies in global economic terms, the political unrest witnessed by the region has caused widespread fears about the prospect of energy supply disruptions. With international oil and gas prices beginning to rise from 2010, there was serious concern among market and political actors that any further increase in prices would put at risk the fragile recovery of the global economy from the deepest recession in decades. The many historical precedents of oil disruptions in the region did not help allay these anxieties, especially in consuming countries and regions. But although these concerns proved justified - in the sense that disruptions did occur - the short-term effect on oil and gas markets of the recent events in the MENA region have been less dramatic than feared. Why was this so? How did markets react to disruptions in the short term and what does that tell us about oil (and gas) price dynamics, the conditions on oil and gas markets, the importance of MENA oil and gas, and the way in which the effects of the Arab uprisings are likely to manifest themselves in the long term?

This paper examines the significance of the recent Arab uprisings and their implications for regional and global oil and gas markets. It starts by summarizing the importance of MENA oil and gas in global markets, before delving into an assessment of the short-term market reactions to the disruption of Libyan oil and gas supplies. By highlighting the relatively limited effects the Libyan oil and gas outages had on markets, the paper argues that markets were able to cope resiliently, owing primarily to the availability of sufficient spare oil production capacity in the system, lower post-recession gas demand in Europe, and ample 
LNG supply. The main argument of this paper is that a) the implications of ongoing political changes in the MENA region will be more important in the long term; b) these implications will manifest themselves mainly through energy policy changes; and c) these changes are important mainly because of the expectation that global oil and, to a lesser extent, gas market fundamentals will be tightening in the years ahead.

\section{MENA oil in global markets}

The importance of MENA oil cannot be over-emphasized (Table 1). MENA is by far the most well-endowed region in the world. In 2010, it held 816 billion barrels of proven oil reserves, with Saudi Arabia alone accounting for almost 20 per cent of the world's oil reserves. In the same year, the region produced 29 million barrels per day (b/d), accounting for more than a third of the world's total production. Unlike many other oil producers, MENA exports the bulk of its oil production, and thus the region has a dominant position in international trade of crude oil. In 2010, the region's exports constituted more than 40 per cent of the world's crude oil exports. Spare capacity is concentrated in the three Gulf Cooperation Council (GCC) member states of Saudi Arabia, Kuwait, and the UAE, with Saudi Arabia holding the bulk of the world's available spare capacity. This has allowed the Kingdom to act as a swing producer, filling the gap at times of oil supply disruptions. Finally, the GCC reserves are among the cheapest in the world to find, develop, and produce (with the exception of Oman). The IEA estimates total production costs in Saudi Arabia, Kuwait, and the UAE to vary between $\$ 3$ and $\$ 5$ per barrel of oil produced. ${ }^{1}$

\section{Table 1: Some Basic Facts about MENA Oil}

\begin{tabular}{|l|c|c|}
\hline & Level (2010) & Share of Global (2010) \\
\hline $\begin{array}{l}\text { Proven Oil Reserves (billion of } \\
\text { barrels) }\end{array}$ & 816 & $59 \%$ \\
\hline Production (mb/d) & 29 & $35 \%$ \\
\hline Consumption (mb/d) & 9 & $40 \%$ \\
\hline International Exports (mb/d) & 21.8 & $100 \%$ \\
\hline Surplus Capacity (2010) & 4 & $2 \%$ \\
\hline
\end{tabular}

Source: BP Annual Statistical Review, 2011; EIA, Short-Term Energy Outlook, August 2011 


\section{Security of MENA oil supplies}

Given the region's key position in the global oil market, the security of MENA supplies has been central to oil importers' energy policies. In addition to their high dependency on such a strategic resource, an underlying security concern for oil importers is that the regular flow of oil may be subject to physical disruptions, limiting the availability of oil supplies and causing sharp rises in oil prices. Since the large oil price shocks of the 1970s, it has been widely argued that developments in oil markets have had large macroeconomic effects on OECD countries and the global economy. ${ }^{2}$ The transport and aviation sectors - the lifelines of a modern economy - are still almost totally reliant on refined crude oil products. Thus, some analysts consider that the most important facet of energy security is 'limiting vulnerability to disruption given rising dependence on imported oil from an unstable Middle East'. ${ }^{3}$ For instance, President Obama is the latest to join a long line of US presidents who have made pledges to cut oil imports and end US dependency on 'foreign' oil.

Such calls to reduce dependency on the region should come as no surprise. The recent Libyan oil disruption is but one in a long series of disruptions caused by political events in MENA (Table 2). Over the years, the region has witnessed wars, civil conflicts, invasions, revolutions, and terrorist acts which resulted in loss of oil output and sharp increases in the level and the volatility of the oil price: The Iranian nationalization between 1951 and 1954 resulted in a cumulative loss of 924 million barrels; the Iraqi invasion of Kuwait resulted in a cumulative loss of 420 million barrels during the period 1990-1, while the US invasion of Iraq which began in 2003 resulted in a cumulative loss of more than 1 billion barrels. At the time of writing, the gross loss from the Libyan disruption is close to 300 million barrels, but the figure is bound to rise as Libya embarks on the long path of rebuilding its institutions and infrastructure after the demise of Gaddafi's rule of over 40 years.

Despite these spectacular events, it is important to stress that it has not been all bad news when it comes to the security of MENA energy supplies. The Middle East, and in particular the Gulf countries, continues to act as the main supplier of energy to global markets. Furthermore, in many instances the region has played the role of a swing oil producer, absorbing supply shocks from within and outside the region. From a producers’ perspective, oil is a crucial resource which is key to their political, economic, and social stability. Despite efforts to diversify their economies away from hydrocarbons, the oil sector remains the 
engine of economic growth and development in most producing countries. Oil exports generate most of the foreign revenue needed to meet import requirements. The bulk of the government revenues needed to implement key developmental and social projects, to diversify and industrialize their economies, and to create employment opportunities for the hundreds of thousands of workers entering their labour markets each year is also generated by oil exports. Given the dominance of the oil sector in their economies, producers are also vulnerable to episodes of physical disruption and oil price instability, especially when compared to the more diversified economies in the OECD.

Table 2: Significant Middle East and North African Oil Crises, 1950-2011

\begin{tabular}{|l|c|c|}
\hline Event & Date & Gross Loss (million barrels) \\
\hline Iranian nationalization & $03 / 1951-10 / 1954$ & 924 \\
\hline Suez Crisis & $11 / 1956-03 / 1957$ & 240 \\
\hline Syrian transit fee dispute & $12 / 1966-03 / 1967$ & 63 \\
\hline Six Day War & $06 / 1967-08 / 1967$ & 120 \\
\hline $\begin{array}{l}\text { Libyan price controversy; } \\
\text { damage to tapline }\end{array}$ & $05 / 1970-01 / 1971$ & 351 \\
\hline $\begin{array}{l}\text { Algeria-France } \\
\text { nationalization dispute }\end{array}$ & $04 / 1971-08 / 1971$ & 90 \\
\hline $\begin{array}{l}\text { October Arab-Israeli } \\
\text { War; Arab oil embargo }\end{array}$ & $10 / 1973-03 / 1974$ & 668 \\
\hline Iranian Revolution & $11 / 1978-04 / 1979$ & 297 \\
\hline $\begin{array}{l}\text { Outbreak of Iran-Iraq } \\
\text { war }\end{array}$ & $10 / 1980-12 / 1980$ & 420 \\
\hline Gulf Crisis & $1990-1$ & 288 \\
\hline US Invasion of Iraq & $03 / 2003-06 / 2008$ & 150 \\
\hline Libyan Disruption & $03 / 2011-$ continuing & 230 \\
\hline
\end{tabular}

Source: Authors' own calculations based on EIA.

The impact of disruptions on oil market dynamics is not uniform and depends on a number of factors, including the causes of disruption, their nature, their length, and the prevailing market conditions at the time. Disruptions and dislocations can also occur at any segment of the supply chain. The supply chain from the resource holder to the end user is very long and includes refining, international and local transportation, storage, and delivery facilities. The impact of a supply disruption also depends on market conditions at the time - i.e. whether the market is tight and whether there is enough surplus capacity in the system.

In analysing oil supply disruptions, it is important to distinguish between short-term effects, manifested in the immediate loss of output and the impact this has on short-term price 
behaviour, and long-term effects that result in the loss of productive capacity and reduction in a country's long-term supply and export potential. Some disruptions - such as those caused by terrorist attacks - have a limited impact on global oil supplies and on productive capacity, and while they attract a lot of media attention, their effect on oil market dynamics is shortlived. In contrast, some other disruptions - notably those caused by international conflicts and civil war - are likely to impact oil supplies and long-term productive capacity. Unilateral sanctions, such as those currently imposed by the USA on Iran, and more recently on Syria, have limited impact on global oil supplies as countries can divert oil flows to other destinations. However, their long-term effects on productive capacity is likely to be large, as sanctions limit technology transfer and reduce the country's access to international funding.

\section{The immediate impact of the Arab uprisings on oil markets}

Contagion fears. The overthrow of President Ben Ali of Tunisia in January 2011 took many people by surprise. Because of its relative prosperity and the tightness of the grip Ben Ali's regime had on society, Tunisia was among the MENA countries least expected to witness a revolt, let alone one that would lead to the removal of its long-serving president. However, as the dramatic events that had began on 17 December continued to unfold into the opening weeks of 2011, and the endgame of the Tunisian uprising became clearer, outside reactions concentrated on anticipating the wider implications of an eventual 'contagion' effect on neighbouring countries.

With the spread of anti-government protests to Egypt towards the end of January 2011, concerns were raised about oil traffic through the SUMED pipeline and the Suez Canal. While Egypt is a modest oil producer with limited export potential, the Suez Canal, which connects the Red Sea and Gulf of Suez with the Mediterranean Sea, is an important transit route for crude oil and refined products. In the first 10 months of 2010, total oil flows (crude oil and refined products) through the Suez Canal amounted to 1.96 million b/d, more than 60 per cent of which was refined products. Over the same period, crude oil flows through the SUMED pipeline amounted to 1.15 million b/d. ${ }^{4}$ However, concerns about the disruption in oil shipments through Egypt did not last long. It became clear during the early days of the unrest that the Egyptian army was determined to ensure that no disruption to the operations of the Suez Canal took place. Even the closure of the Suez Canal would not have resulted in the 
loss of oil volumes. However, it would have increased the cost of shipping, as Middle East cargoes would have had to be diverted, increasing journey times.

The unfolding events in Egypt, which resulted in the fall of President Hosni Mubarak on 11 February, represented a turning point in the dynamics of the Arab uprisings. Rather than treating the unfolding events in the region in isolation, many analysts feared that the Arab uprisings could spark a 'domino effect' throughout the Middle East and North Africa, including the oil-rich Gulf States. Events in Bahrain reinforced such fears. In February 2011, thousands of Bahraini protesters, inspired by popular revolts in other parts of the region, took to the streets. The Bahraini government responded with a security crackdown that caused the death and injury of several protestors.

While Bahrain is not an oil exporter, its geopolitical relevance cannot be overemphasized: the toppling of the Bahraini regime would pose a fundamental risk to its key strategic partners in the Gulf, especially to its neighbour Saudi Arabia. The prospect of increased Iranian influence in the region which this would induce is a risk none of the GCC states is prepared to put up with, especially because Iran is perceived to have benefitted from the US invasion of Iraq which allowed it to expand its influence in the region. In March 2011, Saudi and UAE troops moved into Bahrain to help put an end to the revolt and offer protection to the state's assets as part of the GCC Peninsula Shield Force. The entry of Saudi forces into Bahrain escalated the tension between Saudi Arabia and Iran, increasing the risk that Iran would get drawn into the conflict. The deterioration of the already-strained relations between these two key Middle East oil producers led to further anxiety about the prospect of regional instability and the risk it poses to global oil markets. Although concerns about Bahrain have now eased to some extent, some analysts consider that developments in Bahrain could still have the 'potential to redefine some key and fundamental relationships both politically and in relation to the oil market'.

The political repercussions of the Arab uprisings were also felt on the southern borders of Saudi Arabia with Oman and Yemen. In Oman, protesters marched on the streets in February 2011 demanding an end to corruption and better sharing of the oil wealth. After weeks of anti-government protests which resulted in the death and injury of several protestors, the ruler of Oman, Sultan Qaboos, promised programmes for job creation, increased wages for 
nationals, and proposed a general programme for political reform. In response to events in Bahrain and Oman, the GCC promised a massive aid package to help promote economic development in the less-rich GCC states.

In Yemen, demonstrations calling for an end to President Ali Abdullah Saleh's 33-year rule, which started in January 2011, continued to gather force. The government's violent response to protests escalated the tension between the government and the protestors, bringing the country close to the brink of civil war. In a move seen to increase pressure on Saleh's government, tribal fighters made numerous attacks on oil pipelines affecting Yemen's production. (Yemen is a modest oil producer with production of less than 300,000 b/d.)

However, the significance of events in Yemen, Bahrain, and Oman extended beyond their direct impact on oil supplies. Concerns that unrest in these countries could spill into Saudi Arabia and other Gulf States became highly elevated during the months of February and March 2011 and have not yet dissipated. The underlying causes of the unrest are far from being resolved, and the efforts of the USA and GCC have, so far, failed to break the political deadlock either in Bahrain or Yemen.

The Libyan Disruption. Towards the second half of February 2011, events in the Gulf and Egypt were being overshadowed by rapid developments in Libya, the biggest oil reserve holder in Africa and a major crude and product exporter to Europe. The events that followed the 17 February uprising in Libya have been the most dramatic by far in the region since the beginning of 2011, with the revolt turning into a full-fledged civil war. The speed with which events unfolded in Libya was startling. Just two weeks after the start of the protests in Benghazi, the UN Security Council adopted a resolution that imposed wide-ranging sanctions, imposed an arms embargo on Libya, and referred key leaders of the regime to the International Criminal Court. More surprisingly, the Arab League called on the UN Security Council to impose a no fly zone over Libya (with only Algeria and Syria reportedly objecting to the move). This represented an important shift in the dynamics of the conflict in Libya, and provided Arab support for the subsequent NATO action.

In terms of oil market dynamics, events in Libya resulted in the first oil supply disruption since the eruption of the revolution in Tunisia. The Libyan disruption took place amidst 
robust demand growth as the global economy consolidated its recovery from the 2008 financial crisis - one of the deepest since World War II. In 2010, the year-on-year increase in global oil demand amounted to 2.26 million b/d, driven mainly by non-OECD economies (Figure 1). This figure is considered quite high by historical standards. Nevertheless, OPEC's surplus capacity was also relatively high owing to a decline in global oil demand in the aftermath of the 2008 financial crisis, and the coming on stream of new projects in Saudi Arabia in 2009. Just prior to the Libyan disruption, surplus capacity was close to 4 million b/d (Figure 2).

Figure 1: Year-on-Year Change in Global Oil Consumption 2000-10 (mb/d)

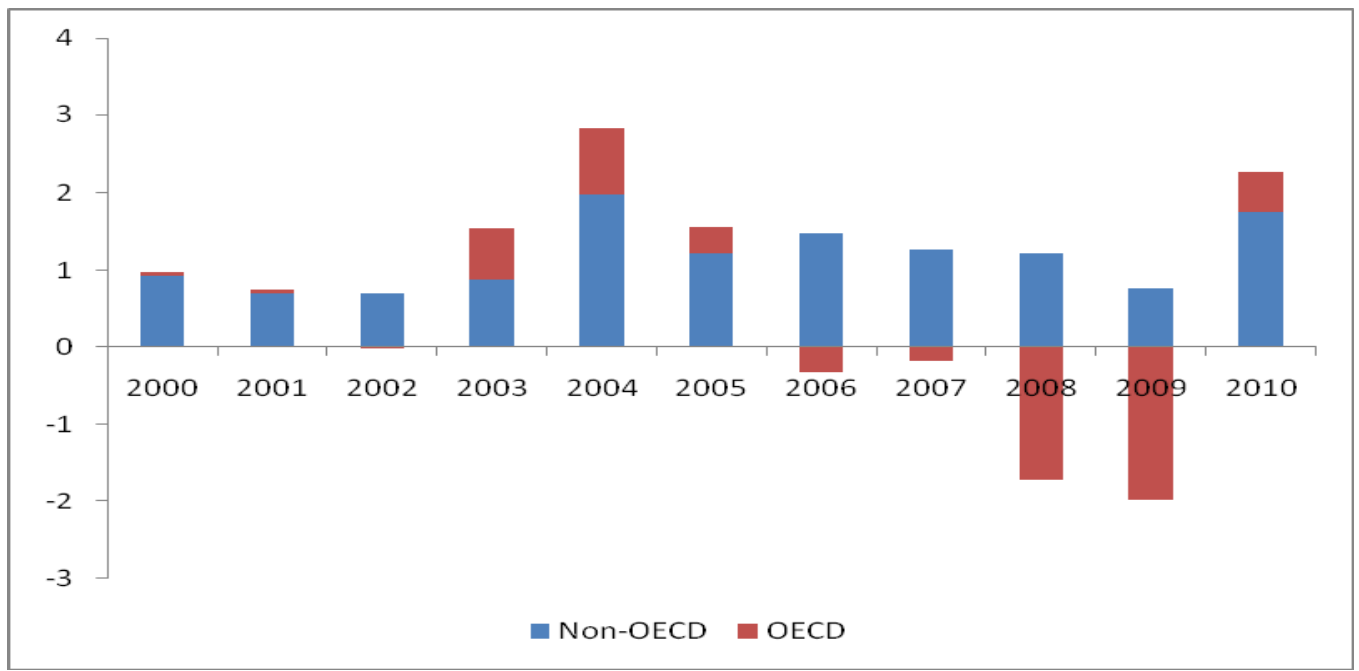

Source: EIA.

Figure 2: OPEC Total Spare Crude Oil Production Capacity 2000-10 (mb/d)

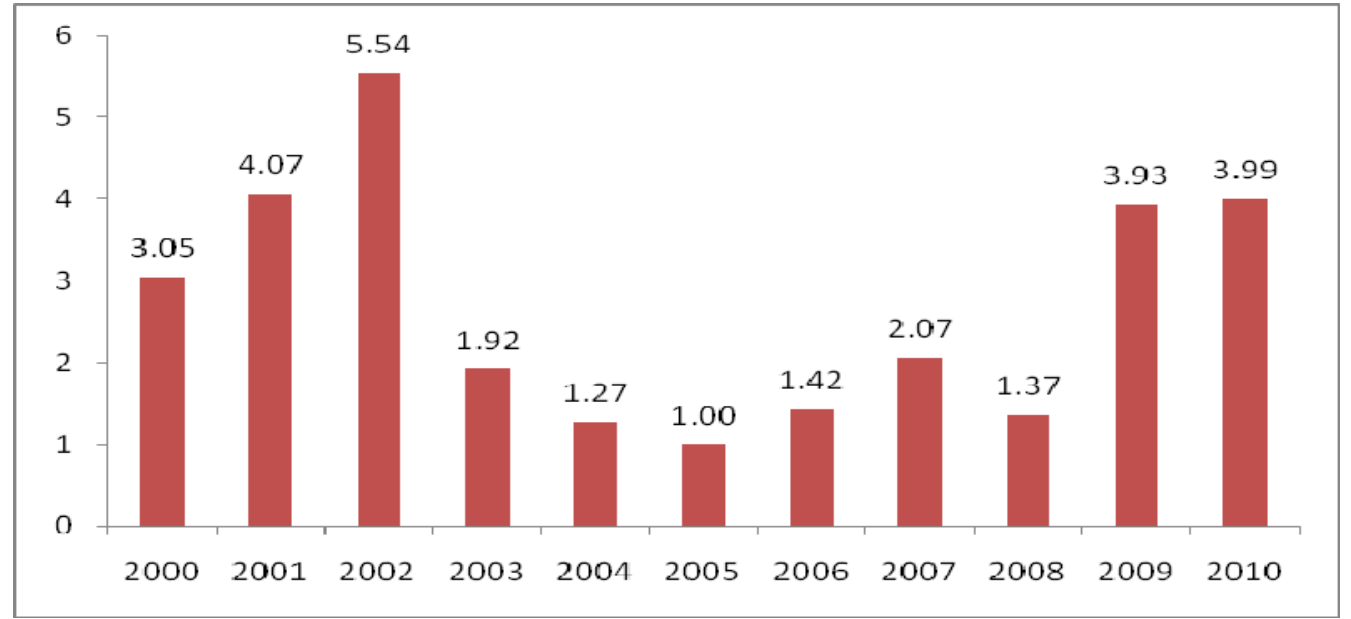

Source: Short-Term Energy Outlook, August 2011 
In terms of volume of crude oil, the Libyan disruption resulted in a loss of 1.6 million b/d, and in addition 136,000 b/d of refined products. In principle, the loss of output due to the Libyan disruption could have been offset by increasing supplies from other OPEC member countries. However, given that Libyan crude oil is mainly light and low sulphur, while most of the available spare crude production capacity was heavy and at the sour end of the barrel, the two crude types were not perfect substitutes. This mismatch in quality complicated market adjustment to the Libyan disruption.

In April, Ali Naimi, Saudi Arabia's oil minister, announced that Saudi production in March was 8,292,100 b/d, having declined from the February level of 9,125,100 barrels per day. ${ }^{6}$ According to the minister, this was a clear indication that the market was well supplied despite the Libyan disruption. A more plausible explanation is that refineries in Europe were searching for low sulphur, diesel-rich crudes, while what was on offer was mainly high sulphur, gasoline-rich crudes. Thus, while the Libyan disruption represented only around a 2 per cent loss out of total global oil production, the global pool of low-sulphur diesel-rich crude oil suffered a serious disruption, with implications for the products markets.

Oil Price Dynamics. As a result of the dramatic events in the MENA region, the geopolitical dimension, which was generally underplayed prior to the Arab uprisings, became central to the analysis of oil market dynamics. Even before the Libyan disruption, the fear of contagion caused market players to take more seriously the probability of disruptions from the region. This new perspective was ultimately reflected in the level and volatility of the oil price. Such threats of disruption were not, however, responsible for the sharp rise in oil prices witnessed towards the end of 2010.

As seen in Figure 3 below, between October 2009 and October 2010, the oil price oscillated within an implicit narrow band of $\$ 70$ to $\$ 80$ per barrel. In October 2010, the oil price broke loose and moved away from the band. This took place well before the start of the Arab uprisings, and occurred mainly in response to the flow of strong oil demand data which was better than previously expected, driven by robust economic performance in non-OECD economies. 
The uprising in MENA reinforced this upward trend in the oil price. However, as shown in Figure 4, there was not a one-to-one correspondence between key political events in the region and oil price movements. The only exception was the start of the Libyan unrest, which caused a sharp rise in the oil price. In part, the market was reacting to an output loss, and also to the geopolitical context in which the disruption took place. Unrest in Libya was not an isolated event, and there were concerns among traders that uprisings would spread and engulf other key oil exporters. The events in MENA also made betting on sharp oil price movements more profitable, attracting speculative financial flows into the market. During February, bets on a potential Saudi disruption proved to be quite attractive for some traders. Although the probability assigned to such an event was quite low, the potential gains in case of an output loss from Saudi Arabia would have been very high. These bets proved unprofitable and positions were reversed causing short-term price volatility.

Figure 3: Europe Brent Spot Price FOB January 2009- April 2011 (\$/Barrel)

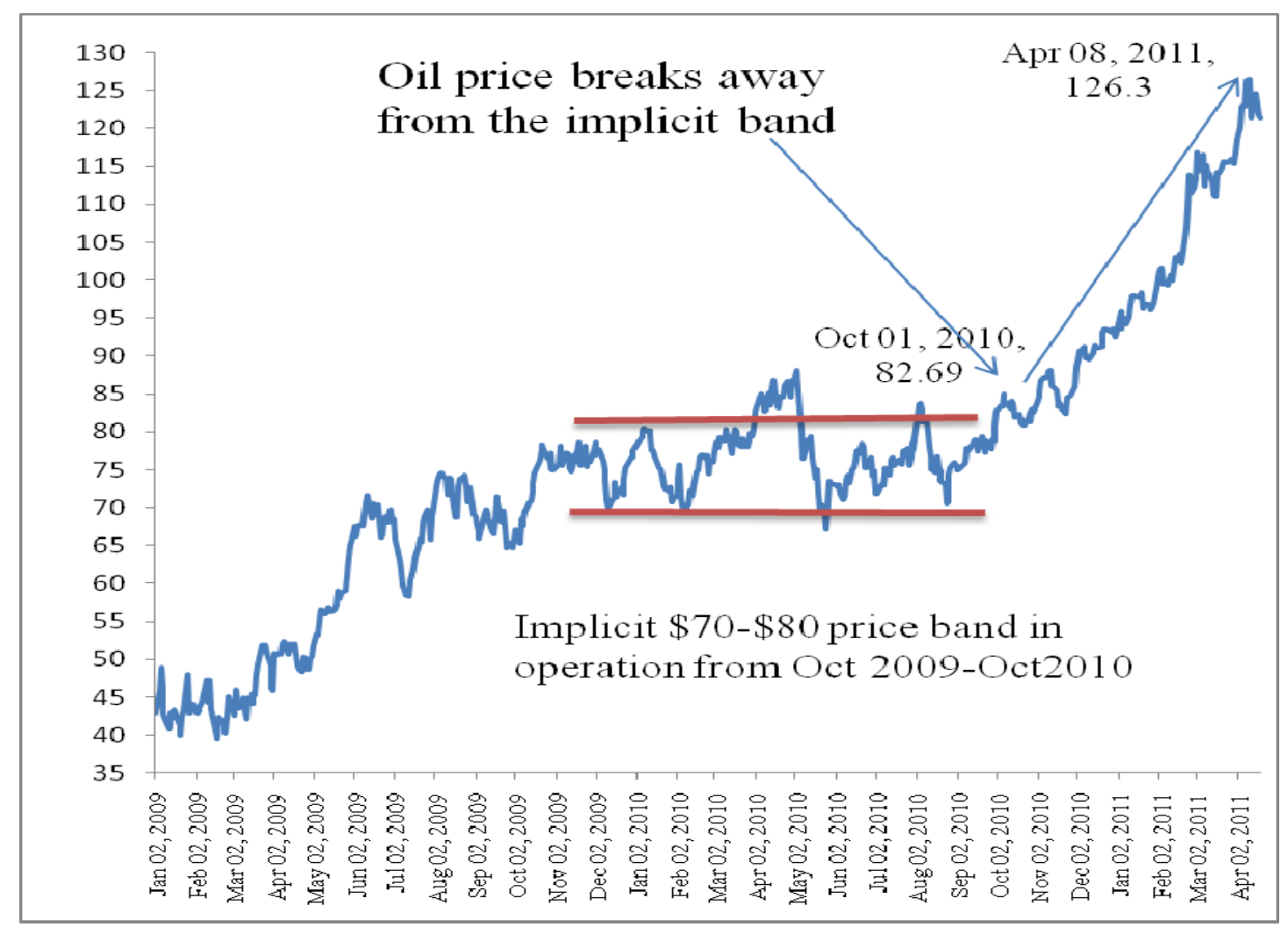

Source: Price data obtained from EIA; Comments are authors’ own additions. 
Figure 4: Key Middle East Events and the Oil Price October 2010-April 2011

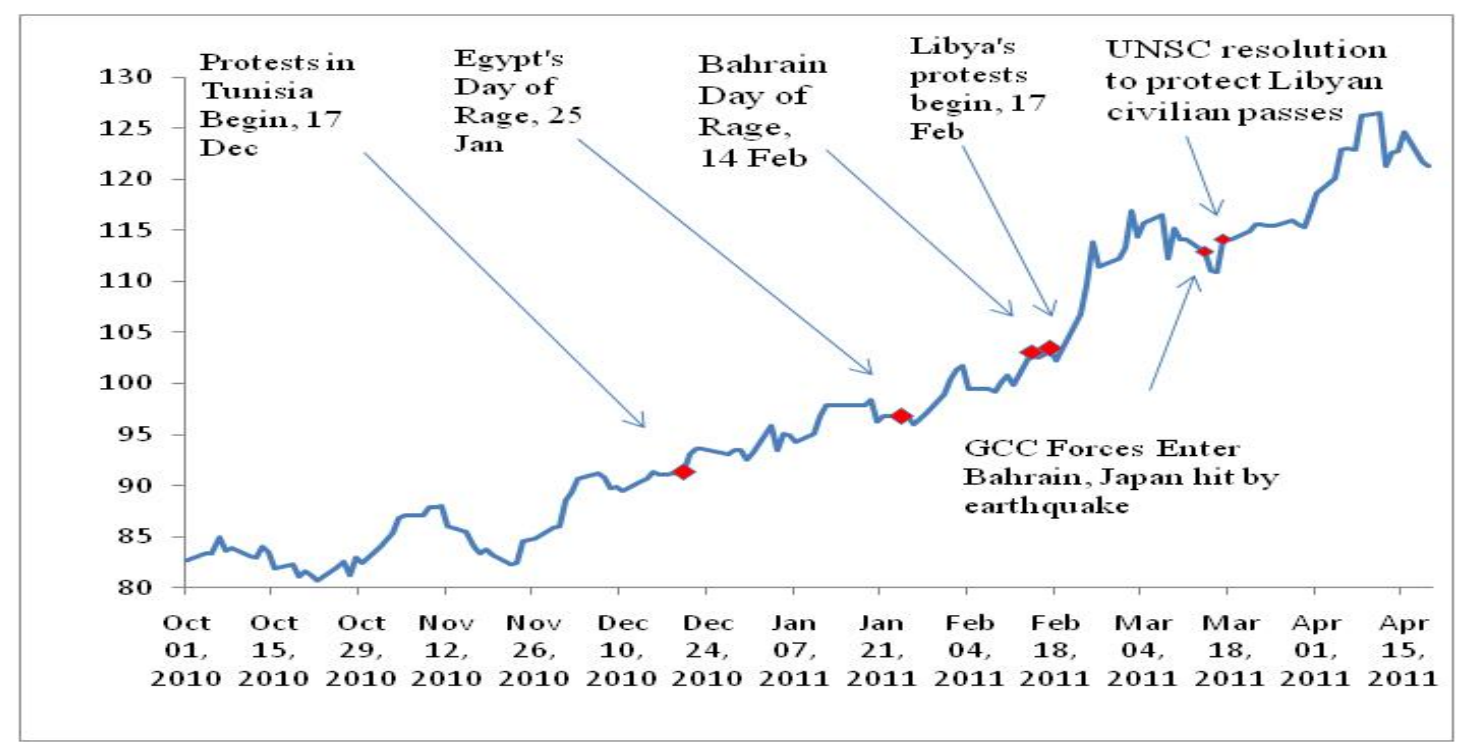

Source: Price data obtained from EIA; Comments are authors’ own additions.

The sharp increases in oil prices in April 2011, and increased inter-day and intra-day volatility, reignited the old debate about the effectiveness of market mechanisms in adjusting to disruptions, and the role of speculators in the oil price formation process. Nevertheless, in hindsight, the oil market and its various players have shown great resilience in dealing with the Libyan output loss. This has occurred mainly through adjustment in price differentials between crude oil markets, time spreads, crude and products markets, as well as between various petroleum products. As Figure 5 below shows, the Brent-Dubai price differential widened considerably in February 2011, increasing from around $\$ 2.50$ at the beginning of January to more than $\$ 8.50$ in mid-April, reflecting the disruption of Libyan exports and lower availability of light sweet crude oil in the market.

The time spreads also narrowed, with the first month-second month price differential for Brent entering into backwardation, reflecting tighter oil market conditions (Figure 6). To attract African crudes, with properties similar to that of Libyan crude, into Europe, refineries had to aggressively bid for these crudes, putting an upward pressure on the oil price. For instance, the price of Nigerian Bonny Light increased from $\$ 98 /$ barrel in early January to more than \$128 in the first week of May. The price differential between Bonny Light and Dated Brent (both light sweet crude oil) increased from less than \$2/barrel towards the end of January to $\$ 4.26 /$ barrel in the first week of April (Figure 7). 
To some observers, these price adjustments have appeared abrupt, imposing an unnecessary cost on consumers. To others, the sharp price adjustment 'is technically unjustified. It is also dangerous'. 7 The latter argument is quite surprising, given that in the oil market, price adjustment is the main mechanism available to clear ex ante excess demand and to shift different types of crude oil across regional markets. Quite to the contrary, one could argue that in the midst of all these transformative political events in a resource-rich region, a stable oil price would have indicated an oil market that was not responsive to events and to the flow of new information, given the revised expectations about the stability of key producers, and a serious supply disruption in light sweet crude oil.

Figure 5: Brent-Dubai Price Differential January-August 2011 (US\$/Barrel)

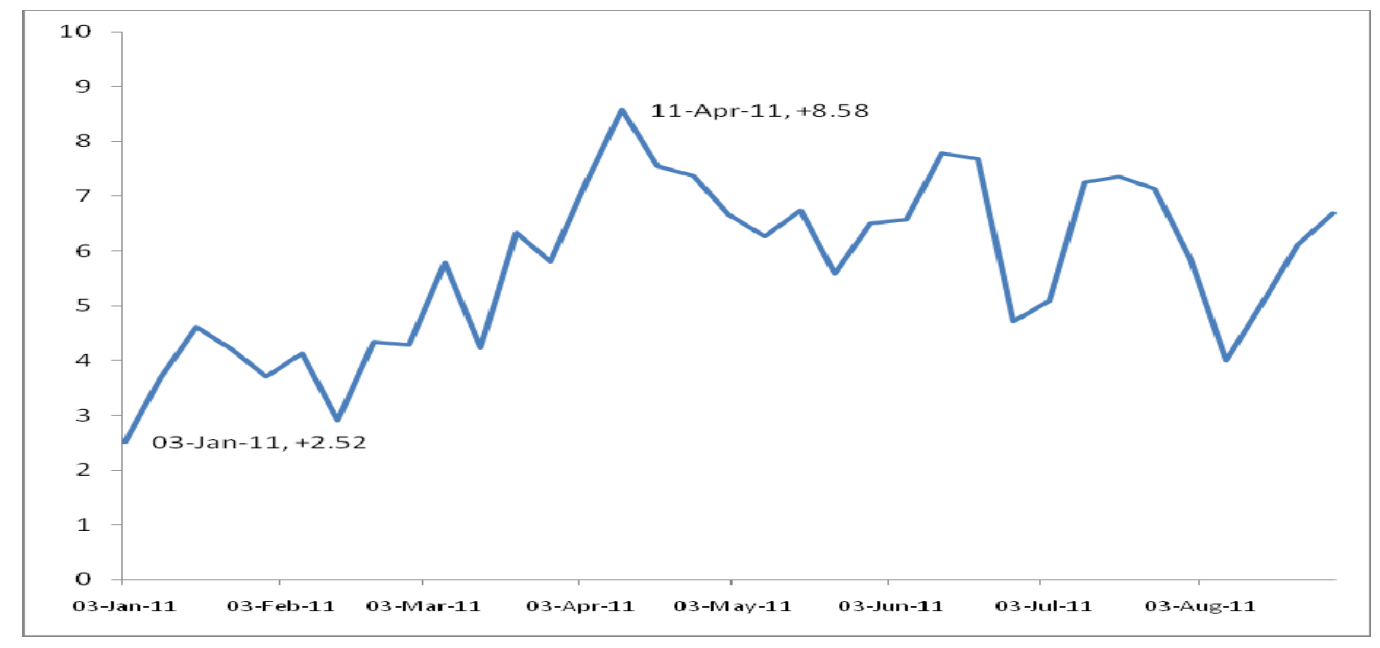

Source: Energy Intelligence, Petroleum Intelligence Weekly.

Figure 6: Brent Term Structure: First month-Second month

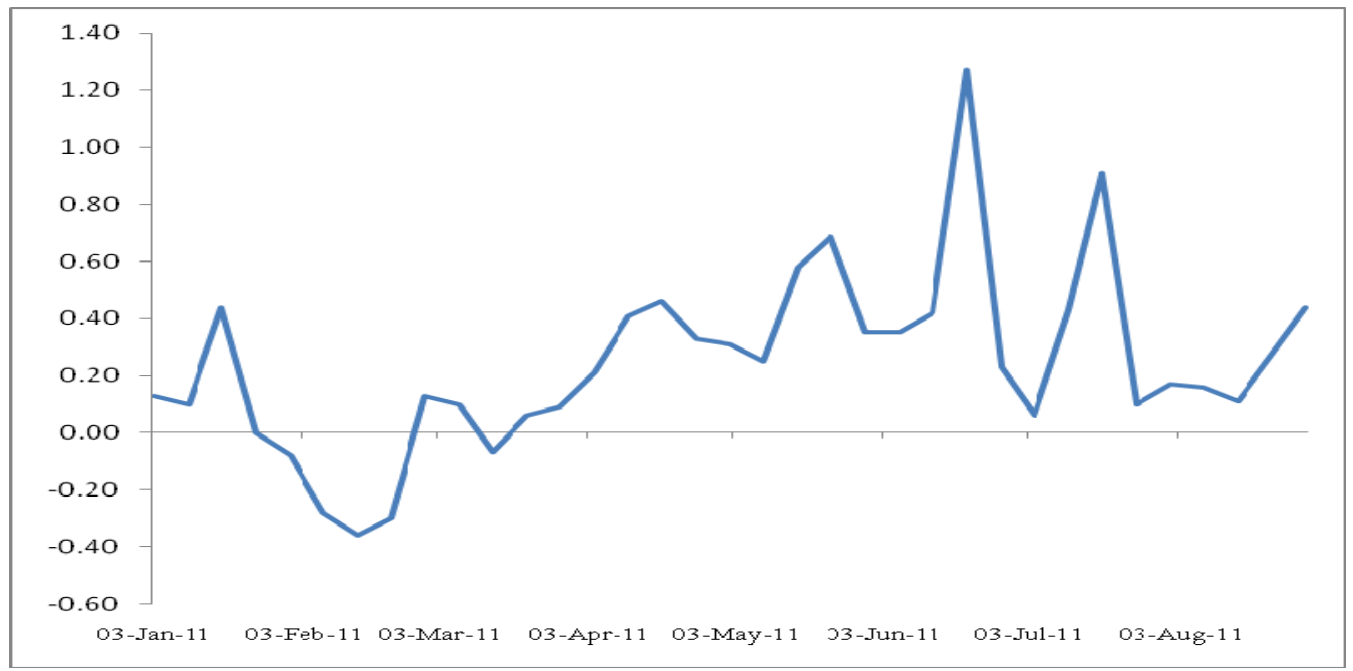

Source: Energy Intelligence, Petroleum Intelligence Weekly. 
Figure 7: Bonny Light-Dated Brent Price Differential January-May 2011 (\$/Barrel)

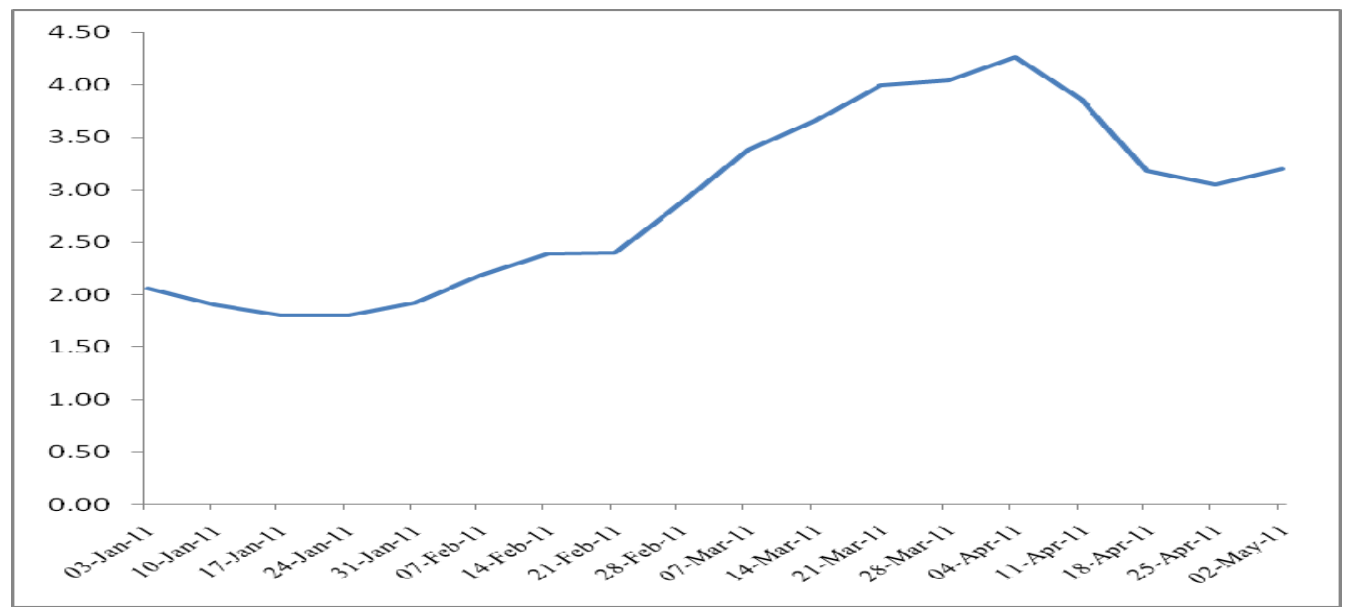

Source: Energy Intelligence, Petroleum Intelligence Weekly

\section{The long-term impact of the Arab uprisings on oil markets}

Notwithstanding the fact that oil markets have shown strong resilience in dealing with the Libyan disruption through price adjustments (mainly in price differentials), use of spare capacity, and shifts in trade flows across regions, one should not overlook the long-term implications of the Arab Spring on the behaviour of key market players and oil market dynamics.

Loss of long-term productive capacity. Historical evidence indicates that civil conflicts and wars have both short- and long-term effects on oil supplies. They often result in short- to medium-term supply losses, with production and export capacity being reduced by worsening security conditions, leading to infrastructure damage and the departure of foreign operators. As the security situation stabilizes, exports to international markets are often resumed within a relatively short period of time (often a few months), driven mainly by a dire need for funds to rebuild the country and to increase social spending. However, historical evidence indicates that it takes an oil exporter a relatively long period of time (often a few years) before it reaches its pre-disruption output level (Figure 8). In countries such as Iraq, Venezuela, and Iran, production levels have never reached the pre-disruption level. Kuwait is an exception; it managed to increase production to the pre-disruption level in a relatively short period of time.

In addition to these effects on oil supplies, wars and conflict can affect a country's long-term productive capacity, reducing its supply potential. This mainly occurs as a result of over- 
ground constraints related to: lack of political consensus which reduces the effectiveness of government in implementing its policies; a volatile security situation; the introduction of a new regulatory framework for the organization of the oil sector and government's relations with foreign players; a change in attitude towards foreign investment in the oil sector; and the possible imposition of sanctions (such as in the case of Iran and most recently Syria).

\section{Figure 8: The Impact of Disruptions on Productive Capacity}

2

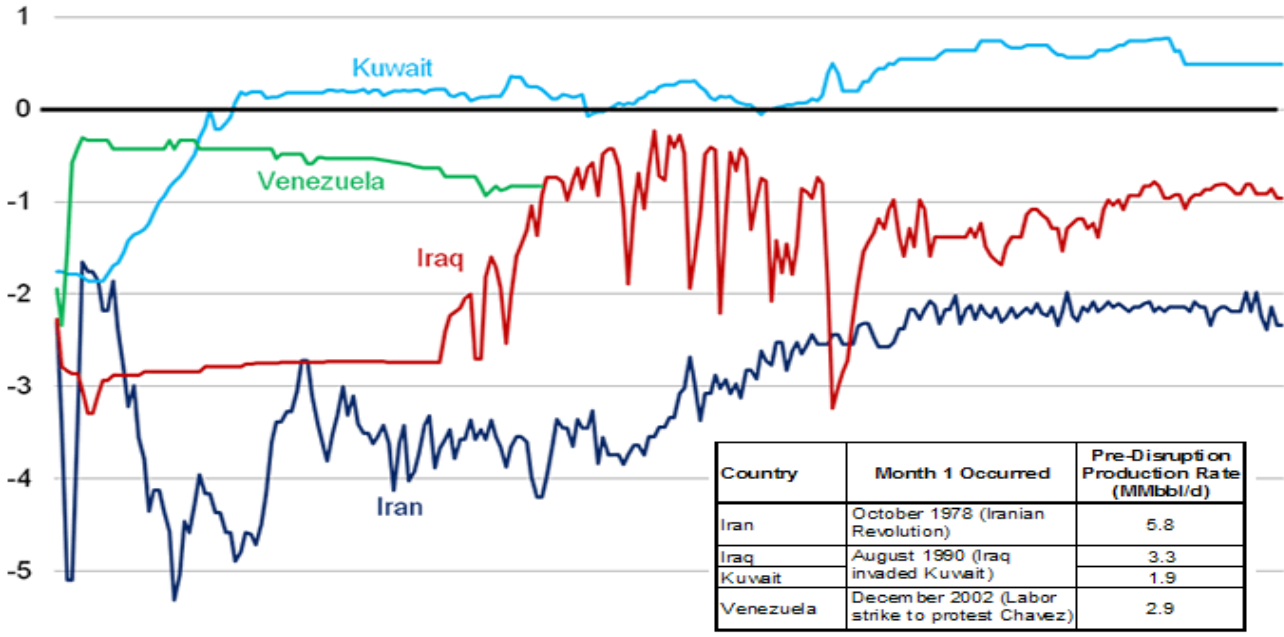

Month $1^{*}$ Year 2 Year 4 Year 6 Year 8 Year 10 Year 12 Year 14 Year 16 Year 18 Year 20

Source: EIA

In the case of Libya, the challenges are immense. In addition to the daunting task of rebuilding the damaged oil fields and oil installations, a major challenge facing the National Transitional Council (NTC) is to create a new political structure and new functioning institutions that will enable it to govern the country and provide political stability and security to the Libyan people and to foreign operators. Unlike Egypt and Tunisia, the country has no constitution, no parliament, weak bureaucracy, no national army, and no political parties or more general civil society organizations. All of these key institutions have to be built from scratch.

In terms of oil policy, the new Libyan government might seek to reorganize the oil sector, a process which may involve revising existing contracts and entering into fresh negotiations with foreign oil companies about local content, the involvement of the national oil company, and the government's share in oil revenues. These negotiations could prove to be quite 
complex and may not necessarily result in more attractive fiscal terms for companies, even those from countries that have shown strong support for NATO action. On other hand, the NTC is in dire need of funds and is eager to resume production, and thus may decide not to revise existing contracts until much later. At oil prices above $\$ 100$ per barrel, oil companies may also have the incentive to accelerate production, and may show some flexibility in negotiations in order to get a toehold in Libya. Most analysts predict a scenario in which Libya would resume its exports in matter of months. However, it may take up to two years before Libya reaches its pre-disruption output level.

In terms of long-term productive capacity, the picture is less clear, as this would depend on many factors, including the new political structure, the security situation, the organization of the oil sector, and the effectiveness of government and its institutions in implementing its policies. The Iraqi case has shown that even after stabilizing the security situation and returning to some normality, initiatives related to the oil sector may face strong local opposition, and issues such as the involvement of foreign players, the nature of the contracts, and the distribution of revenues between regions become the subject of dispute between parties. Even before the Libyan disruption, international organizations such as the EIA were sceptical about Libya's output potential, projecting Libya's output to fall due to harsh fiscal terms, institutional deficiencies, and administrative and bureaucratic challenges (Figure 9).

Figure 9: Projections of Petroleum and Other Liquids Productions in Libya (million b/d)

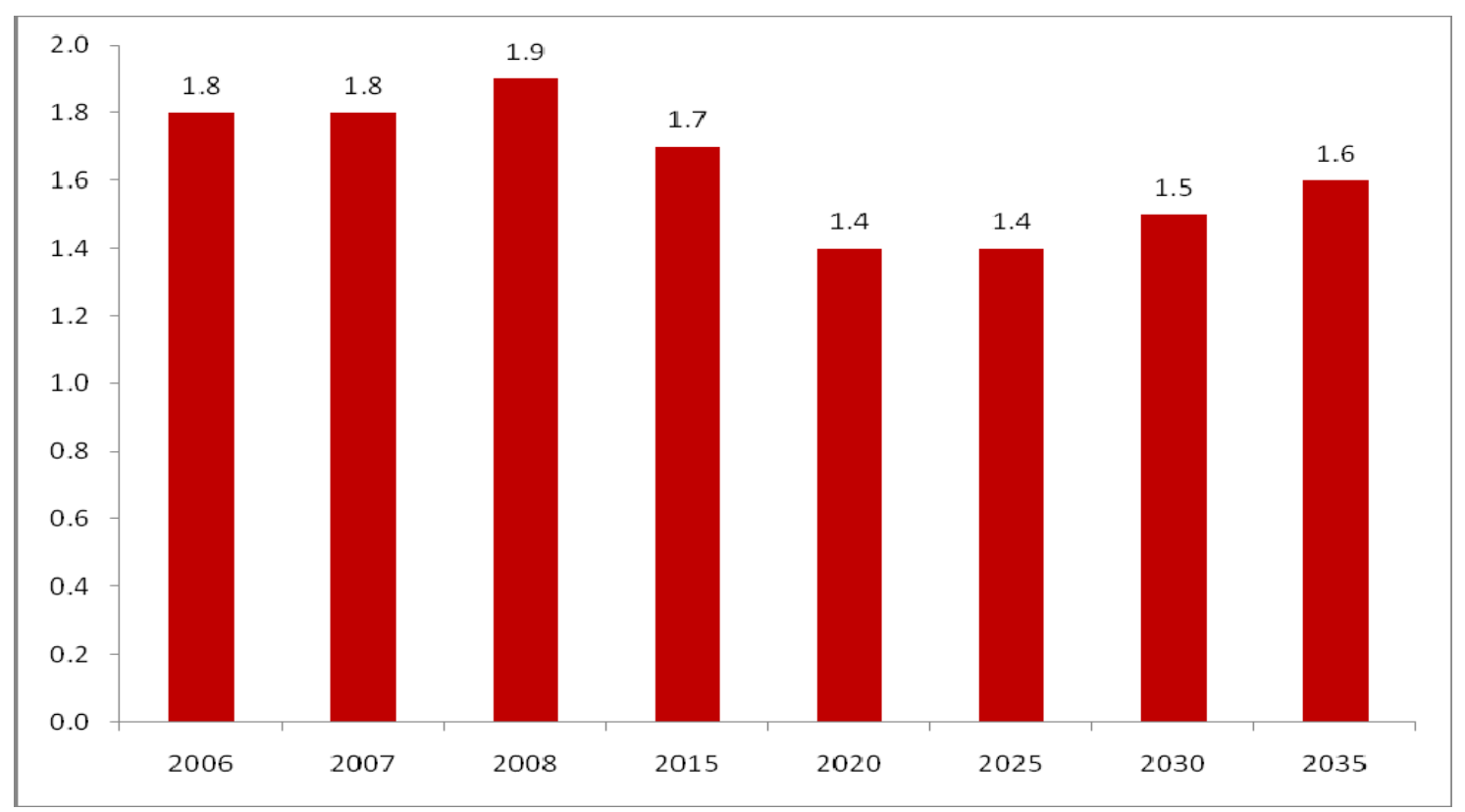

Source: EIA, International Energy Outlook 2010. 
More Frequent Disruptions. As events keep unfolding in the Arab world, the market may have to adjust to more frequent disruptions. The Libyan return to the oil market may not be as smooth as some analysts are predicting, and oil infrastructure could be subject to attacks. In Yemen, attacks on pipelines have become regular and are used by tribes and other groups to apply pressure on the government. The USA and EU have imposed sanctions on the oil sector in Syria, which will eventually result in an embargo on all Syrian oil exports to Europe. While these outages are unlikely to result in large losses of oil output for a long period of time, they are a menace to the oil market, increasing uncertainty and volatility, and refineries' adjustment costs as they seek to replace lost output.

Delay in the reform of domestic energy prices. One of the most striking features of the region has been the rapid increase in domestic consumption of petroleum products. As Figure 10 shows, MENA's share in global oil consumption increased from less than 4 per cent in 1980 to more than 10 per cent in 2010. This rapid growth in consumption can be explained by many factors, including expanding populations, general improvements in standards of living, industrialization policies geared towards energy intensive industries, and a policy of provision of energy at cheap prices to local consumers.

The rationale behind the policy of cheap energy prices varies across MENA countries. In resource-rich countries (but also to some extent in countries with modest reserves, such as Yemen, Syria, and Egypt), cheap energy prices can be considered as one of the various methods of distributing oil rents in order to protect the income of households, which is seen as prerequisite for social and political stability. In oil-rich countries, cheap energy prices are also seen as essential to attract foreign direct investment, and to promote industrialization and diversification in energy intensive industries which are needed to create job opportunities for the hundreds of thousands of workers entering the labour market each year. While such a policy has helped MENA governments achieve some of their objectives, it has placed serious strains on government finances, especially in resource-poor countries. Such a policy has also created serious price distortions, resulting in misallocation of resources and in the 'over-use' of the subsidized good. Consequently, energy intensity in the MENA region has increased rapidly during the last three decades, a trend which runs counter to the rest of the world (see Figure 11). 


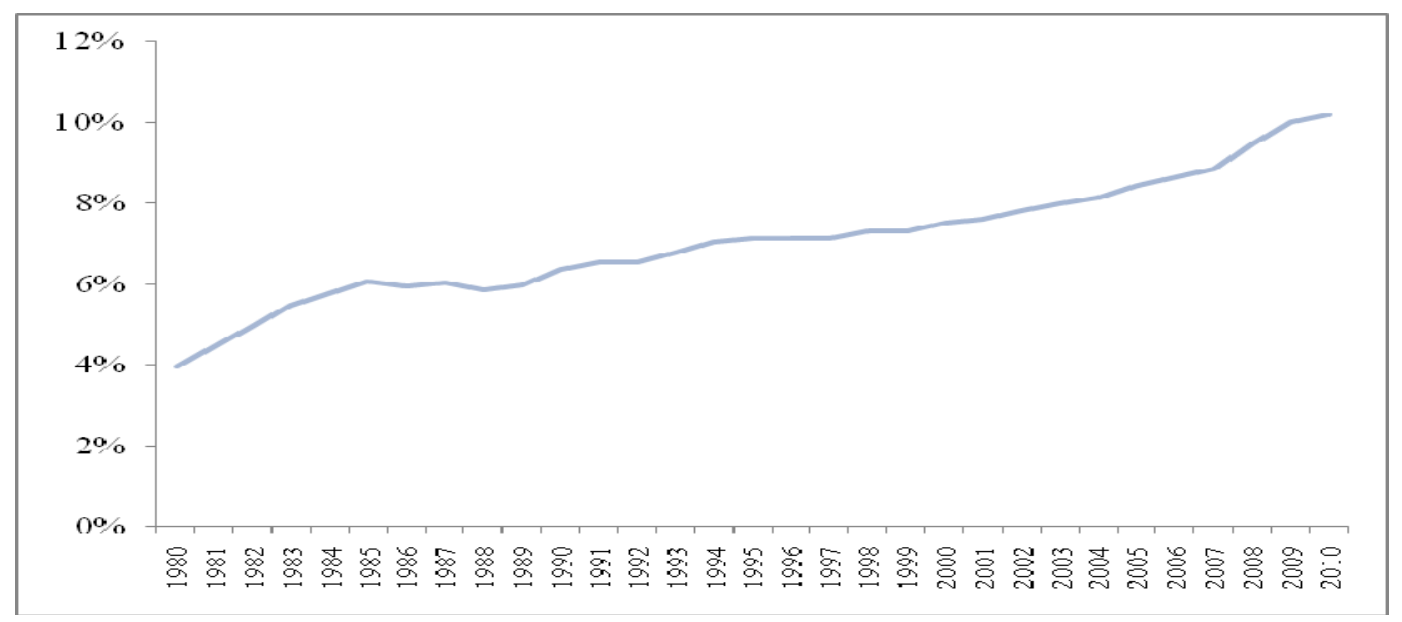

Source: BP (2011)

Figure 11: Total Primary Energy Consumption per Dollar of GDP 1980-2008 (Btu per Year 2005 U.S. Dollars (Purchasing Power Parities))

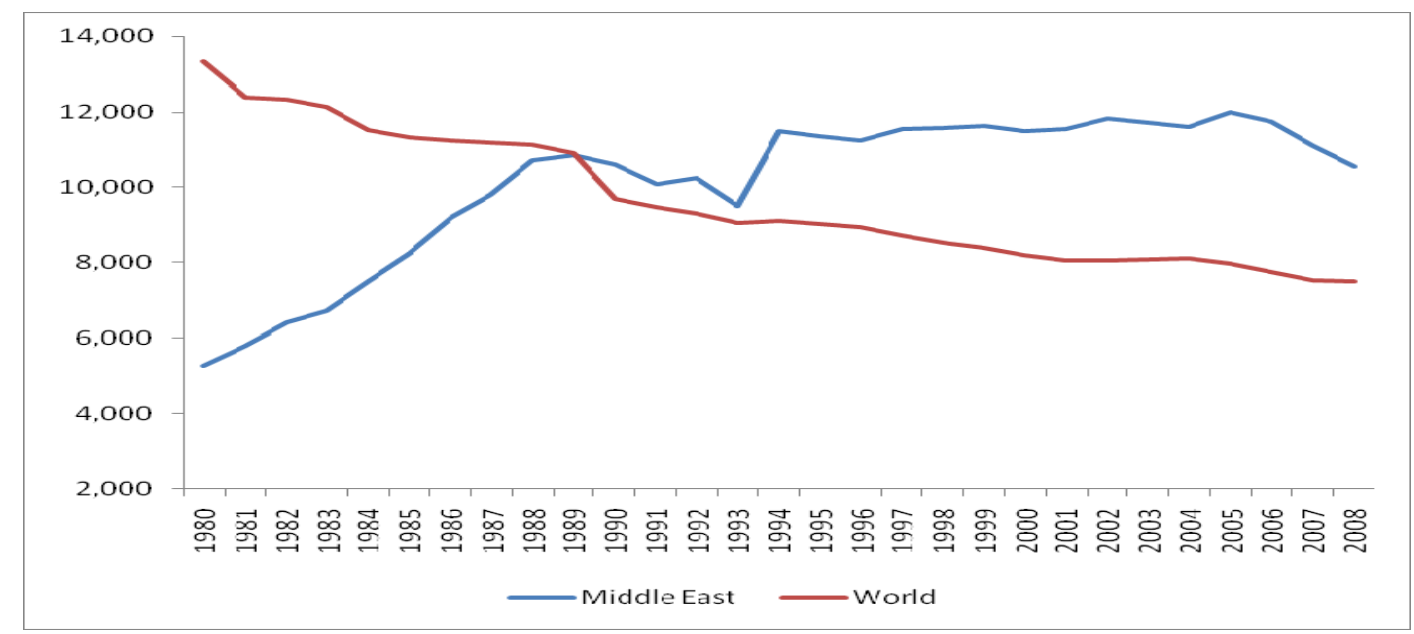

Source: EIA website. Middle East includes: Bahrain, Iran, Iraq, Israel, Jordan, Kuwait, Lebanon, Oman, Palestine, Qatar, Syria, Saudi Arabia, the UAE, Yemen.

While the inefficiencies and misallocation of resources associated with cheap energy prices are well recognized, energy pricing reform efforts in the Arab world have lagged behind those elsewhere. The Arab uprisings will most likely delay any plans for reform. With most regimes feeling threatened by the events sweeping the region, MENA government will be reluctant to increase domestic energy prices during these turbulent times. Without any serious energy pricing reform, it would be difficult to put a dent in the growth of oil consumption in the region. Over the long term, this may affect the export capability of key MENA producers. 
Increase in government spending. In response to popular unrest, many governments in the region, in both resource-poor and resource-rich countries, have increased their social spending. Perhaps this is best illustrated in the case of Saudi Arabia, where the King announced handout packages of around \$126 billion in the first half of 2011. Spending is directed towards key social areas such as housing, employment creation, unemployment benefits, raising minimum wages for government workers, and compensation for increasing living expenses. In Kuwait, the government announced a grant for each citizen of KD1,000 $(\$ 3,500)$ and free food staples in January. Bahrain offered BD1,000 $(\$ 2,650)$ to each household in mid-February, and increased food subsidies and social welfare allowances. In Oman, the government raised minimum wages for national workers by over 40 per cent. These handouts are not likely to be one off, and the pressure for further distribution of rents may persist.

Such sharp increases in government expenditure imply that oil exporters have become even more dependent on high oil prices. Therefore, many analysts expect an increase in the reservation oil price for key producers, and a more assertive reaction if oil prices are to fall to levels deemed unacceptable. For instance, Barclays Capital argues that 'the threshold for active producer involvement in the market is some \$20 to \$25 higher, lending support to an oil price at around \$90-100 per barrel. This perhaps would be one of the biggest differences between 2011 and 2008, when it comes to determining a potential soft floor for prices’ ${ }^{8}$

Many commentators noted that the price needed to balance the budget in Saudi Arabia has risen sharply between 2008 (when the preferred price of \$75 per barrel was announced by the King of Saudi Arabia) and 2011 (Figure 12). However, one should be cautious in using the break-even price as indicative of the new price floor for the world's key producer. Saudi Arabia has no foreign debt, very low domestic debt, and large reserves of foreign currency, and as a result the fiscal buffer is still very large. Furthermore, Saudi Arabia does not have to balance its budget on an annual basis. Nevertheless, the increase in the break-even price implies greater dependency on high oil prices, and one could expect producers to exert tighter control, especially in a falling market. 
Figure 12: Oil Price Needed to Balance Budget in Saudi Arabia 2003-2012

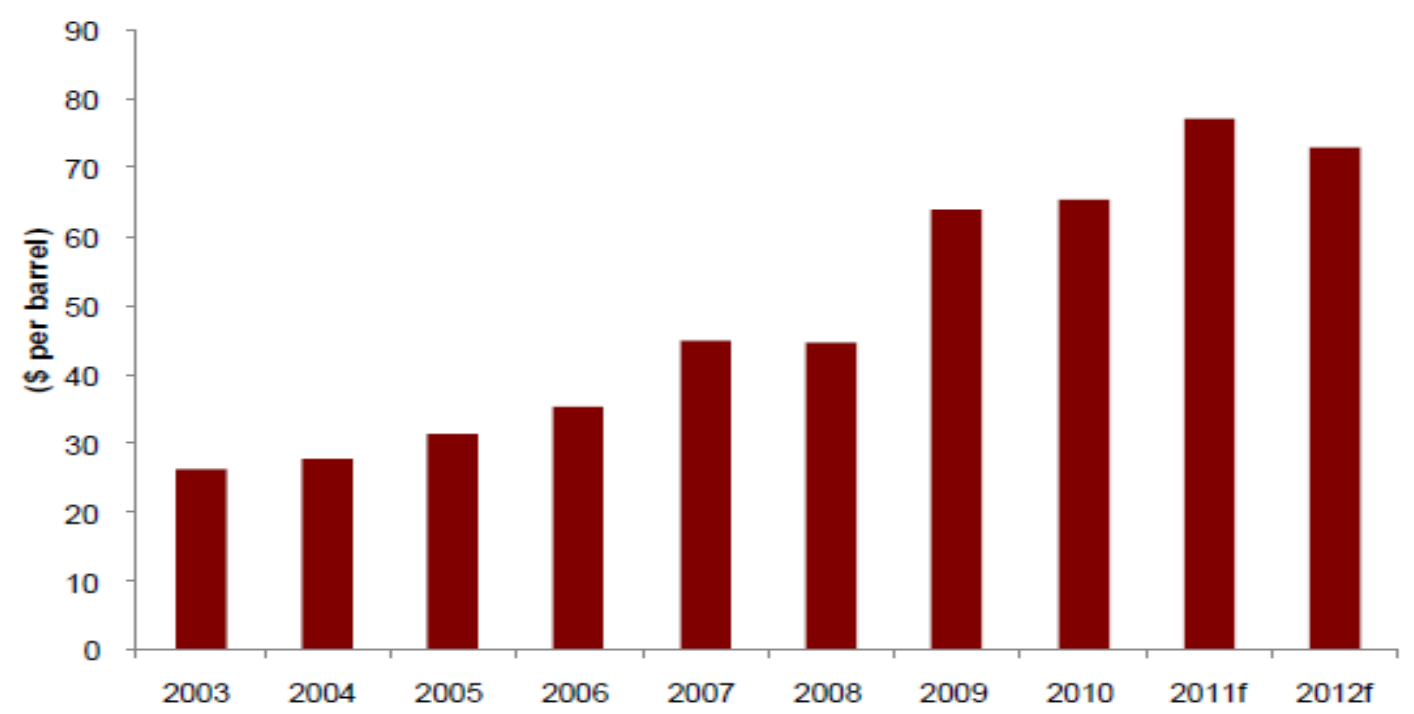

Source: Jadwa Investment

Producer-Producer and Producer-Consumer Relations. To many observers, the approval of the charter of the International Energy Forum in February 2011 represented a turning point in producer-consumer relations. One of the key objectives of the Forum has been to foster 'greater mutual understanding and awareness of common energy interests among its Members'. The Libyan disruption put these relations to the test. In May, the IEA expressed serious concern at the 'growing signs that the rise in oil prices since September is affecting the economic recovery by widening global imbalances, reducing household and business income and placing upward pressure on inflation and interest rates'. The IEA sent a strong signal to producers that 'there is a clear, urgent need for additional supplies on a more competitive basis to be made available to refiners to prevent a further tightening of the market'. If these supplies are not made available, then the IEA will 'consider using all tools that are at the disposal of IEA member countries', hinting at the release of strategic stocks. ${ }^{9}$

OPEC's response to these calls was muted. At its meeting on 8 June, OPEC members could not reach a consensus, and the GCC proposal to hike output was rejected by six member countries (Libya, Angola, Algeria, Ecuador, Iran, and Venezuela). The meeting reflected a deeply divided organization. While there were divergent views about the prospects of the global economy and the need to put extra oil into the market, the meeting was overshadowed by political tensions. Iran was angered by the entry of GCC forces into Bahrain. Venezuela, and Algeria have opposed the NATO-led military intervention in Libya, a move supported by 
the GCC. Libya's opposition to the GCC proposal did not come as surprise, as Qatar was one of the first countries to officially recognize the Libyan NTC. MEES summed up the mood:

OPEC is no stranger to disagreements and political tension - either among member countries or with the wider international community. But even by the organization's standards, this meeting was held under unusually stressful conditions. And, while delegates declined to admit it publicly, political tensions almost certainly played a part in the failure to reach an agreement. ${ }^{10}$

On 23 June, the IEA decided to release 60 million barrels of oil from emergency stocks 'in response to the ongoing disruption of oil supplies from Libya. This supply disruption has been underway for some time and its effect has become more pronounced as it has continued'. ${ }^{11}$ However, not everyone was convinced and many considered that the IEA's decision was motivated by the USA in an attempt to cool gasoline prices at the pump rather to meet a supply gap. Regardless of the underlying motive, the fact is that the release of strategic reserves was not part of a coordinated effort between producers and consumers. As a result, the announcement sent a weak and confusing signal to the market, and consequently the impact of the IEA's stock release on the oil price level was short-lived. Instead, the move created chaos in the market, especially for movements in price differentials. Anticipating that Saudi Arabia would react by cutting its own output, the light-heavy crude oil price differential narrowed from $\$ 7.69$ in the week before the announcement to $\$ 4.72$ in the week after, with the differential exhibiting high volatility in the following few weeks (Figure 13).

Figure 13: Brent-Dubai Price Differential June-August 2011 (US\$/Barrel)

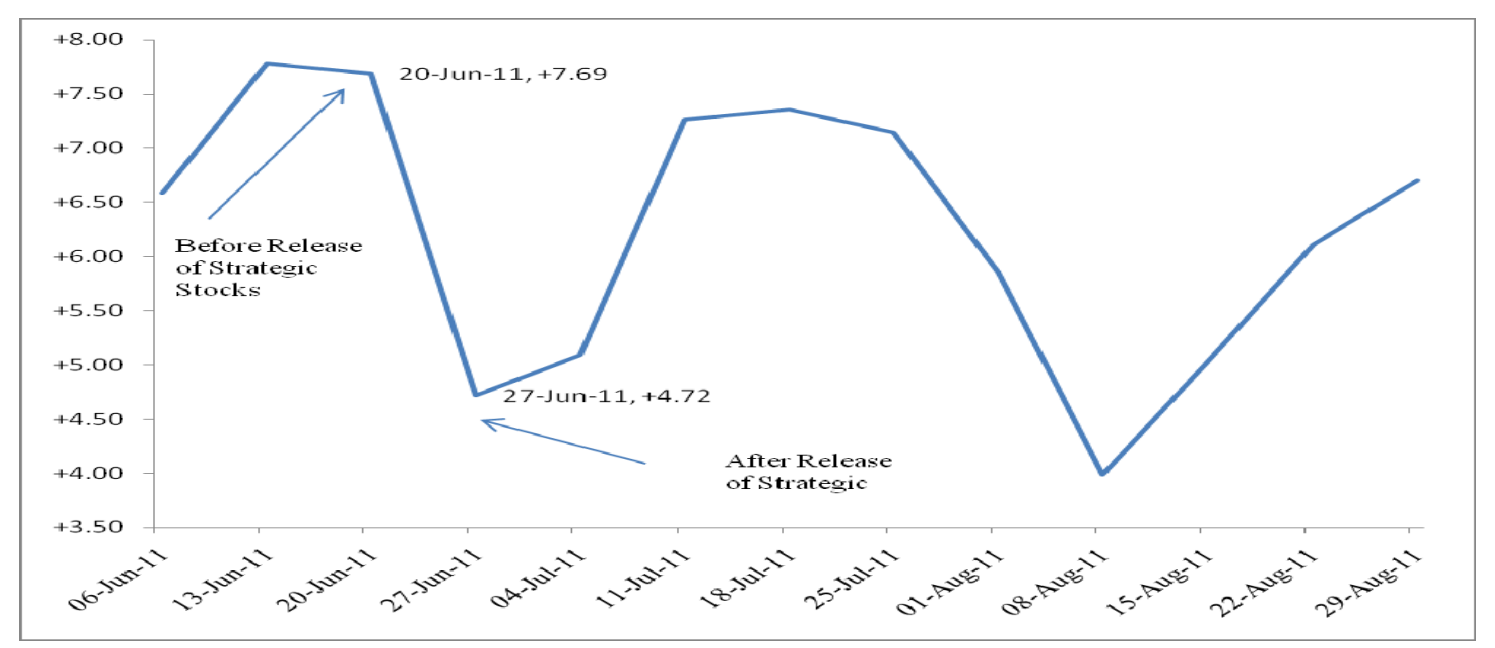

Source: Energy Intelligence, Petroleum Intelligence Weekly. Comments are authors’ own additions. 
Thus, the impact of producers' and consumers' actions has not been neutral on oil price dynamics. Their actions revealed a rift in producer-producer and producer-consumer relations which would need time to be rebuilt. At a deeper level, the June events revealed a market in which its key players have failed to coordinate their efforts in the face of a serious disruption, and rather than smoothing the cost of adjustment, they exacerbated price volatility.

\section{MENA gas in global markets}

Like oil, the natural gas resource base of the MENA region is considerable, both in absolute terms and in relation to global gas reserves. The region holds over 84 trillion cubic metres (Tcm) of proven gas reserves, which represent some 45 per cent of the world's total known reserves. At today's production rate in the region, these reserves would last almost 150 years. And with the upstream potential of most countries in the region being underexplored, a lot more conventional and unconventional gas resources undoubtedly remain to be discovered. However, the distribution of the proven reserves amongst MENA countries is conspicuously uneven, with Iran, Qatar, Saudi Arabia, the UAE, and Algeria accounting for over 87 per cent of the total resource base.

While the region sits on sizable gas reserves, its marketed production in 2010 amounted to only 622 billion cubic metres $(\mathrm{Bcm})$, or 20 per cent of the world's total output. With gas consumption growing rapidly over the last 10-15 years, driven largely by demand for electricity, which in turn has been fuelled by sustained economic and population growth and artificially-low feedstock and output prices, 72 per cent of the gas produced in the region is consumed locally. This trend is set to continue, making the MENA region one of the fastest growing gas demand centres in the world (Figures 14, 15).

One of the implications of this trend is that, overall, the MENA region will continue to play a relatively modest role in international gas trade. Over the last decade, its share of global pipeline gas exports has not exceeded 12 per cent, with Algeria, Egypt, Libya, Iran, and Qatar being the only exporters of pipeline gas. Of the five MENA pipeline exporters, only Algeria, Iran, and Libya send gas outside the region, mainly to Italy, Spain, and Turkey. However, in 
terms of LNG trade, MENA has played a more important role, accounting for about 44 per cent of total shipments in 2010 (Figures 16, 17). This is in large part due to the recent expansion of Qatar's liquefaction capacity, which now stands at over $100 \mathrm{Bcm} / \mathrm{yr}$, and the development over the last ten years of LNG production industries in Oman, Egypt, and Yemen.

Figure 14: MENA vs. World Gas Production, 1999-2010

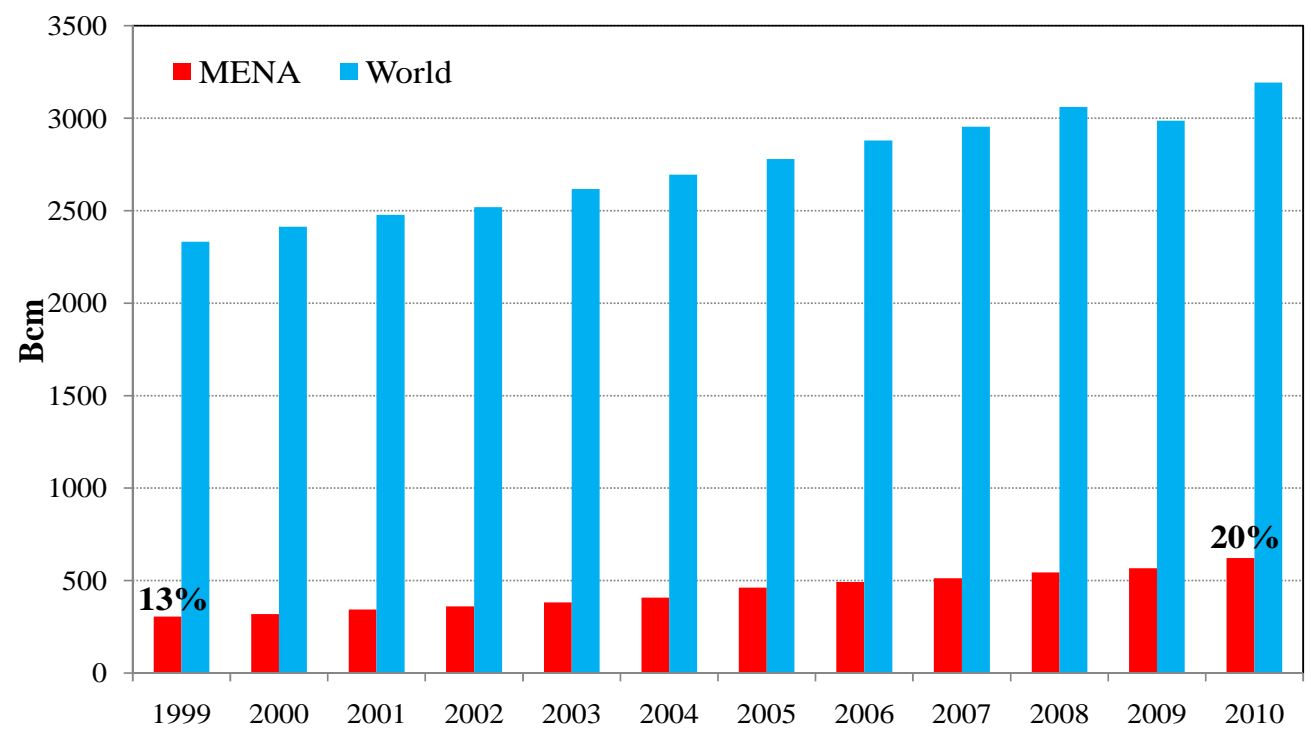

Source: BP (2011)

Figure 15: MENA Gas Consumption, 1999-2010

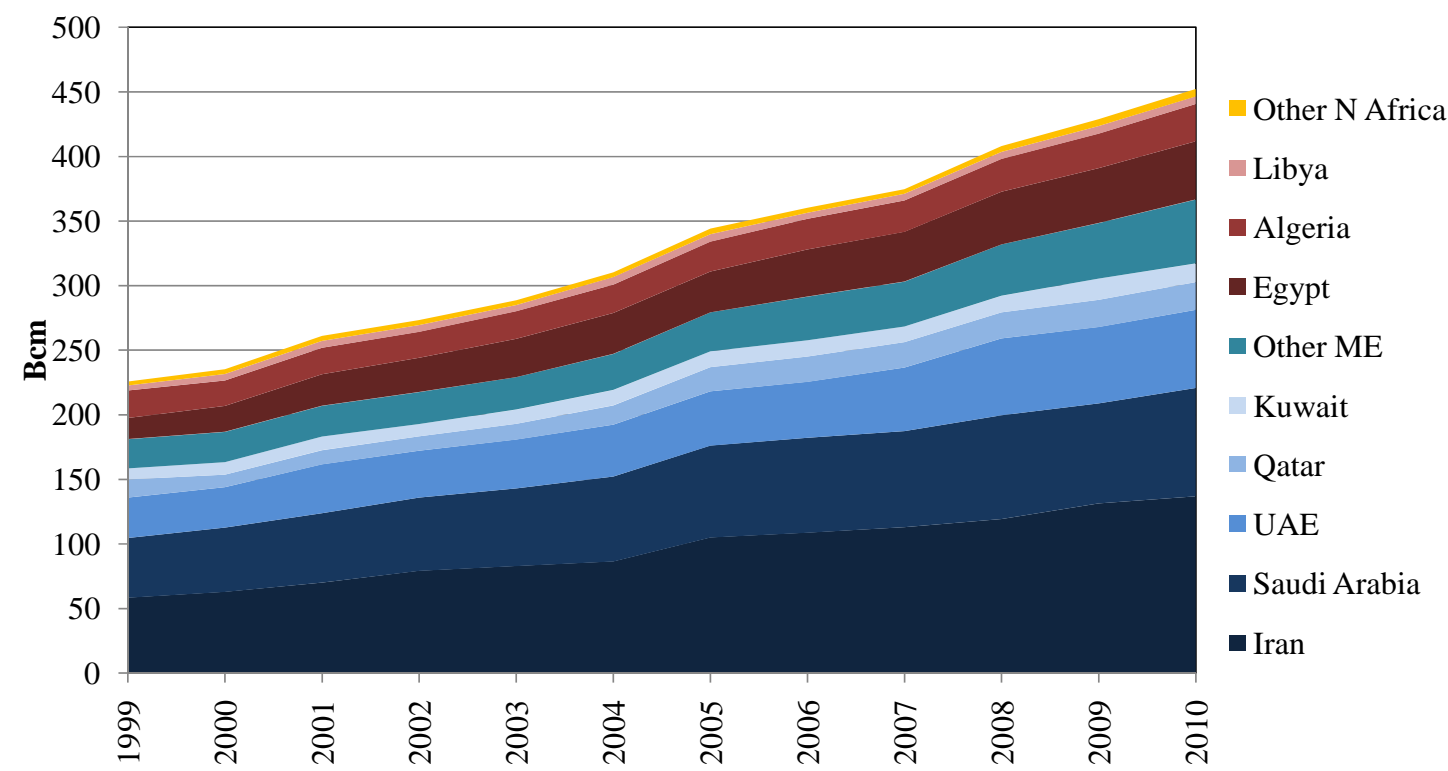

Sources: BP and Cedigaz 
Recent years have also seen the number of gas importers in the region increase from fewer than a handful, to more than half of the 17 countries that make up Middle East and North Africa. Iran, Israel, Jordan, Kuwait, Lebanon, Morocco, Oman, Syria, Tunisia, and the UAE are all gas importers. Bahrain - and possibly Egypt - will join the ranks of these countries by 2015. Although some of these countries are not short of gas resources, it is often their inability to articulate coherent downstream and upstream gas development policies that has led them to face growing gas shortages. The absence of meaningful regional integration, and the prevalence of antagonistic neighbourly relations between countries in the region have also generally tended to prevent the optimization of gas trade between the MENA countries that are 'gas-short' and those that enjoy a gas surplus. ${ }^{12}$

Figure 16: MENA vs. World Gas Pipeline Exports, 1999-2010

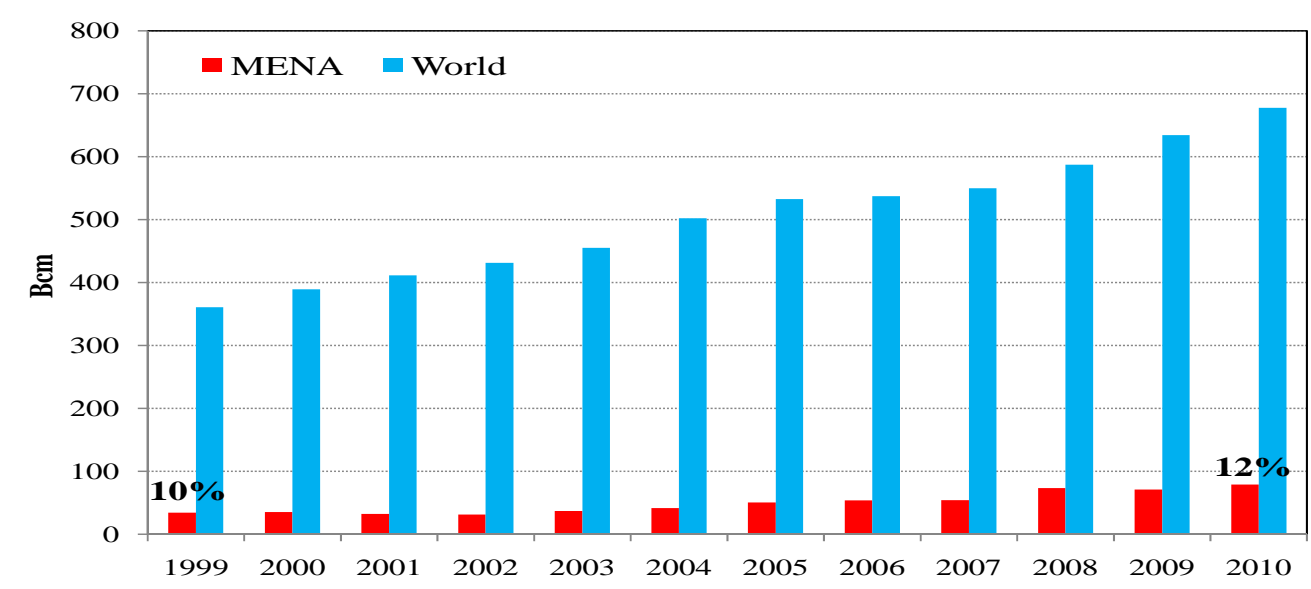

Sources: BP and Cedigaz

Figure 17: MENA vs. World LNG Exports, 1999-2010

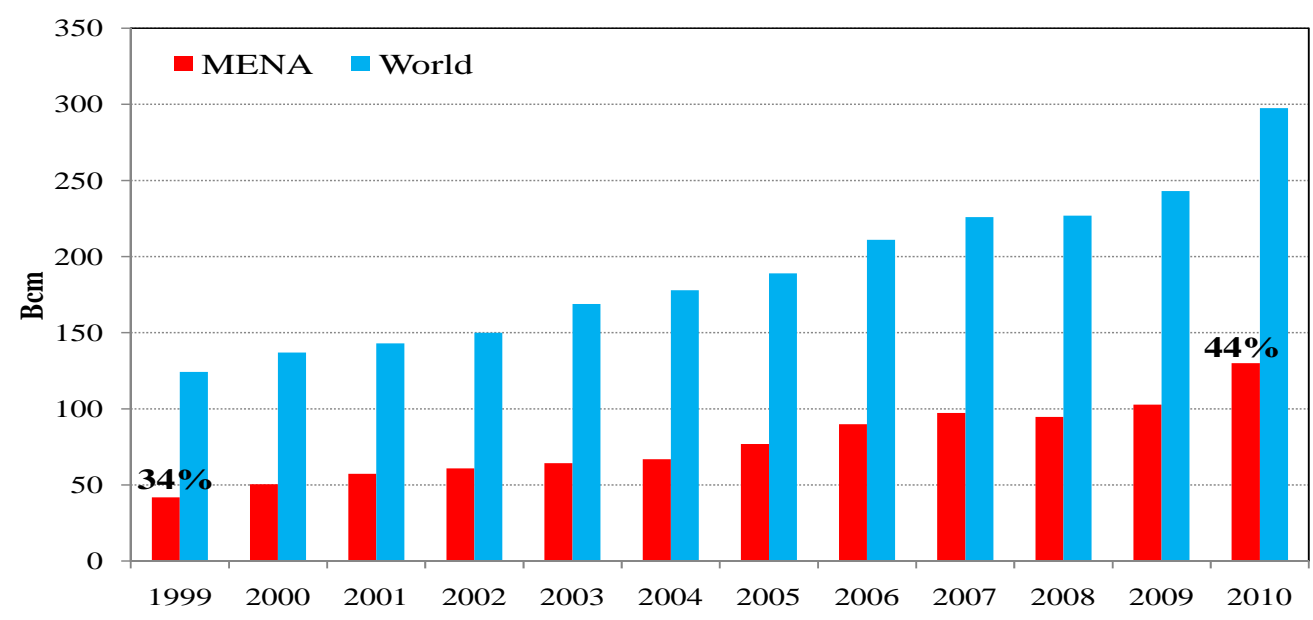

Sources: BP and Cedigaz 


\section{Security of MENA gas supply}

Unlike oil, the history of MENA gas supply has been much less problematic. For a start, and despite the fact that gas supply chains are less flexible than those for oil, natural gas has hardly been as politicized a commodity as oil, especially when it comes to the MENA region. However, the last 15 years or so have seen a notable shift in attitude towards gas, particularly amongst politicians and political commentators: the fuel's share in the primary energy balances of OECD and other economies has been growing steadily; the import dependence of the major demand centres, especially Europe, has become more important; and the increase in international LNG trade has led to more interaction and interdependence between regional markets. This perceptual change was reinforced by the disruptive impact on gas supply to Europe of the 2006-9 transit and pricing disputes that Russia had with Ukraine and Belarus, and by the corresponding realization that gas could also be used by governments as a means of international influence and power projection.

Until the mid-2000s, Algeria accounted for at least half of overall MENA gas exports and for the bulk of the region's gas exports to Europe (Figure 18). Thus, until relatively recently, any concern about the security of MENA gas supply would in all likelihood have been provoked by events and developments in Algeria and their potential impact on the ability of Sonatrach to bring gas to market and meet its contractual obligations. This was particularly the case in the 1990s, when the country was engulfed by a political and economic crisis that threatened the very viability of the state. 
Figure 18: Share of MENA Gas in EU Imports, 2000-10

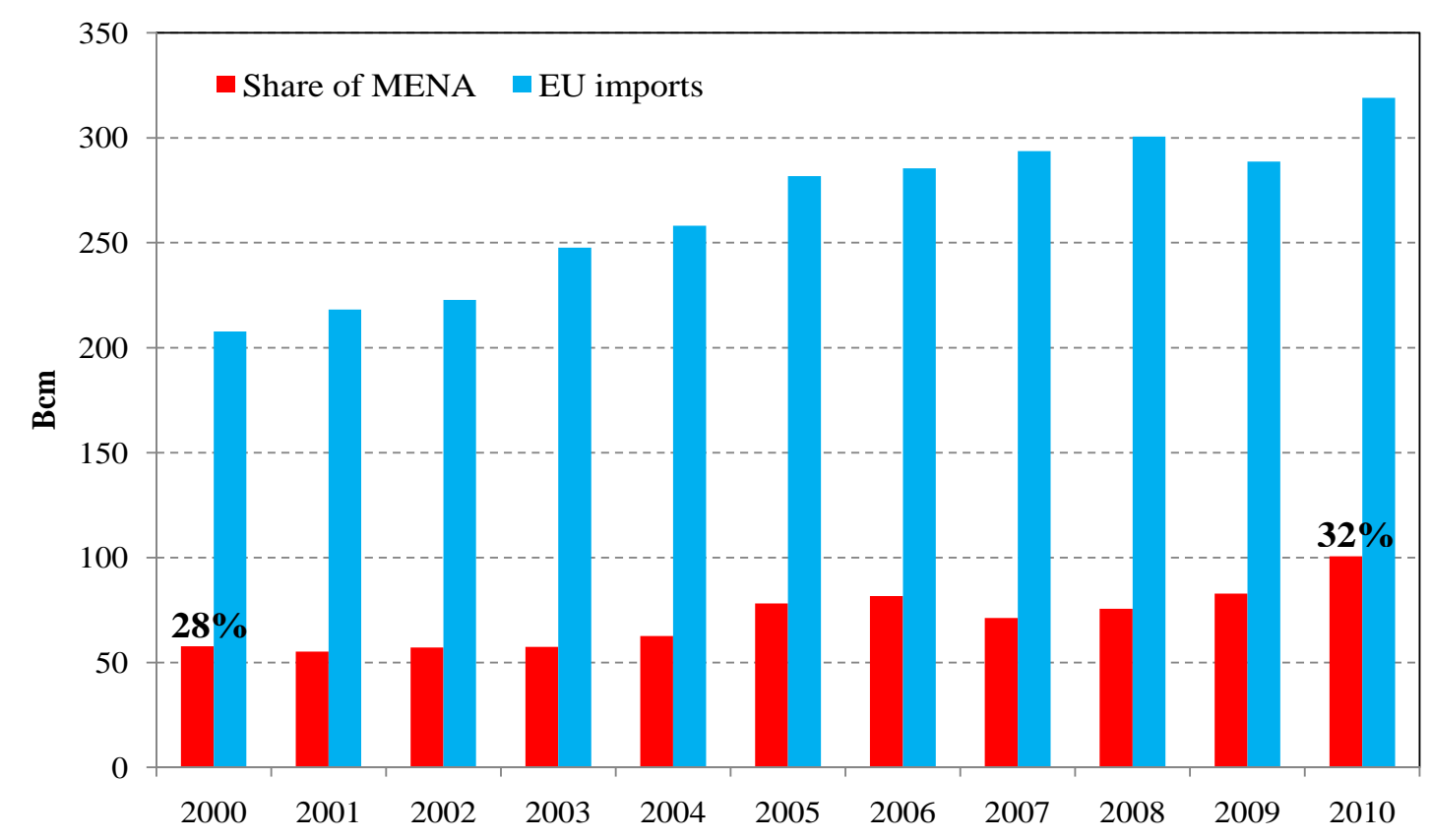

Sources: BP and Cedigaz

However, even in the most unstable of times, the reliability of Algerian gas supplies remained largely intact. Only two serious supply incidents have been recorded in the last 20 years: the first took place in November 1997 when the Algerian section of the Trans-Med pipeline to Italy sustained a terrorist attack that led to the disruption of gas flows through Tunisia for four days; the second incident (unrelated to terrorism) consisted of an explosion that occurred in January 2004 at the Skikda LNG plant, destroying some 3 Bcm/yr of liquefaction capacity. The impact of the resulting disruptions on gas security for Algeria's customers was, in both instances, mitigated by favourable market conditions and the diversity of Sonatrach's gas export infrastructure in terms of both pipeline and LNG.

Iran, the MENA region's largest gas-resource holder and second oldest pipeline exporter after Algeria, has been selling gas to Turkey since 2001. After a 30-year history of failed export projects, the start of gas deliveries to Turkey was considered an achievement by Iranian gas industry standards. However, the Iran-Turkey gas relationship has been fraught with difficulties and commercial disagreements between the two sides. Apart from the fact that traded gas volumes have yet to reach the stipulated annual contract quantity (ACQ) of 10 $\mathrm{Bcm} / \mathrm{yr}$, owing largely to the limited availability of gas supply for export in Iran, gas flows have witnessed several interruptions over the last decade. ${ }^{13}$ While the impact of these 
disruptions on Turkey's gas balance has by and large been fairly limited, given that the Turkish gas market has been well supplied from other sources, they have nevertheless reinforced longstanding doubts about the ability of Iran to play an important role as a gas supplier in the region - let alone for Europe or Asia - at least in the short term.

Gas exports by other MENA countries to customers outside the region come mostly in the form of LNG. Algeria, Libya, and Abu Dhabi, the oldest LNG exporters in the MENA region, have in the last 15 years been joined by Qatar, Oman, Egypt, and Yemen, which have added a combined $145 \mathrm{Bcm} / \mathrm{yr}$ (106 mtpa) of liquefaction capacity to the existing $37 \mathrm{Bcm} / \mathrm{yr}$ (27 mtpa). Most of this new capacity is in Qatar, which having achieved its $105 \mathrm{Bcm} / \mathrm{yr}$ (77 mtpa) production target in 2010, is now by far the largest exporter of LNG in the world.

Although there is no history of major LNG supply disruption in the MENA region, its growing share in global LNG production and trade, and the concentration (over 91 per cent) of the regional installed productive capacity in Qatar and Algeria, naturally raises serious concerns among LNG buyers in Europe and Asia about the risk of a major disruption, because of political instability in parts of the region. A particular cause for concern in this respect is the growing reliance of Middle East exporters on strategic transportation channels or 'chokepoints'. Most of the LNG exported from the Gulf countries flows through just three channels, all of which are susceptible to disruptions because of major accidents, piracy, terrorist attacks, or war. These are the Strait of Hormuz, the Bab el-Mandab passage, and the Suez Canal. Qatar and Abu Dhabi are particularly vulnerable given that all of their LNG exports (up to a $113 \mathrm{Bcm} / \mathrm{yr}$ ) transit through the Strait of Hormuz, with the spectre of a regional conflict adding to their vulnerability, bearing in mind that most of their production and transport infrastructure is located a stone’s throw away from Iran.

The rising importance of the MENA region in global LNG trade coincided with the formation of the Gas Exporting Countries Forum (GECF) in 2001, and the growing suspicion among gas importers since then that the GECF marks the onset of a 'gas OPEC'. In the early years of its existence, the GECF lacked a coherent purpose, leading many observers to be doubtful about the prospect of its turning into an effective price-setting, volume-controlling organization. $^{14}$ 
However, with the adoption of a charter in 2008, and the setting up in the following year of an executive office and a permanent secretariat in Doha, the GECF appears to be taking itself more seriously than most commentators had been prepared to concede. Furthermore, the ratcheting up of political rhetoric in favour of increased cooperation between the most influential permanent member of the Forum, namely Russia, Qatar, Algeria, and to a much lesser extent Iran, led to renewed anxiety among European consumers in particular, who feared that Moscow would use the Forum to undermine their ability to diversify sources of gas supply away from Russia.

It was, however, Algeria that led the most explicit effort to date within the Forum to cut supply and affect spot gas prices. In 2010, the Algerian energy minister, who was holding the rotating presidency of the GECF, called for coordinated supply action in order to reverse the recession-induced depression of spot gas prices on the Atlantic Basin and stave off the resulting pressure from buyers on oil indexation in long-term supply contracts. Although it served as a reminder that the most active members of the GECF (in addition to Russia and Venezuela) have so far been from the MENA region (Qatar, Algeria, Iran, and Libya), the lack of response to the Algerian initiative from Qatar and Russia confirmed that effective coordinated action within the Forum was still constrained by the divergent commercial and political interests of the bigger members.

\section{The immediate impact of the Arab uprisings on MENA gas supply}

As mentioned above, the outbreak of unrest in Tunisia took many people by surprise, and the dramatic ousting of its long-serving president was even more startling. The revolution in Tunisia had almost no impact on international markets, but the regional events it set in motion caused widespread concerns about the risk to energy supplies from other countries. Tunisia itself is a relatively marginal player in regional and global economic terms. A net importer of gas, it is, however, an important transit country for Algerian gas flows to Italy through the Trans-Med pipeline, which has a nameplate capacity of about $33 \mathrm{Bcm} / \mathrm{yr}$. The risk posed by the Tunisian unrest for transit security did not become apparent until after the removal of Ben Ali on 14 January. The following Tuesday, an unusual dip of more than 40 per cent in Trans-Med nominations through the Tunisia-Sicily stretch of the pipeline was recorded, causing serious concern in Italy and Algeria. Although nothing apparently sinister was behind the blip, and normal flows resumed shortly thereafter, the incident served as a 
stark reminder of the risk to gas supply from North Africa posed by political instability in the region. This vulnerability was thrown into sharper relief by reports months later of a failed bomb attack on the Trans-Med pipeline. ${ }^{15}$ Algeria is Italy’s biggest gas supplier, and relations between Sonatrach and ENI have historically been exemplary. Despite the fact that ownership of the gas is transferred to ENI at the Algerian border with Tunisia, there is little doubt that any serious transit disruption would cause enormous distress to both parties.

With the spread of anti-government protests and associated unrest to Egypt, concerns within the gas industry shifted to supply as well as transit risks. Besides controlling and operating the Suez Canal - one of the main strategic shipping points through which an increasing number of LNG tankers have been passing in recent years (over 14 per cent of 2010 global LNG trade) - Egypt has since the mid-2000s become an important supplier of gas in the Mediterranean and Atlantic Basin. In 2010, Egyptian gas production stood at over $61 \mathrm{Bcm} / \mathrm{yr}$, with exports of about $15 \mathrm{Bcm} / \mathrm{yr}$, two-thirds of which was in the form of LNG and the rest transported by pipeline to Israel and the Mashreq markets of Jordan, Syria, and Lebanon.

Although Egypt's ports were closed for the day on 31 January, when a million Egyptians were expected to protest in central Cairo, the Suez Canal continued to operate normally, both during and after the uprising, under the supervision of the army. However, the unrest contributed to greater market uncertainty, leading to added pressure on oil prices and shipping charter rates. Yet despite the repatriation by IOCs of international staff during the three week uprising that led to the ousting of President Mubarak on 11 February, Egypt's gas production - over 75 per cent of which originates in the offshore Mediterranean - appeared largely unaffected. Likewise, LNG production saw no major interruption, although according to Waterborne LNG output in February 2011 dipped by more than 25 per cent year-on-year. However, this decline was somewhat offset by an increase in production in the following two months owing, reportedly, to the availability of additional volumes of gas feedstock from the industrial plants affected by civil unrest.

Fears about the risk to Egyptian gas supplies materialized when a series of five explosions between 5 February and 30 July rocked gas infrastructure near Al-Arish, in the Sinai, leading to repeated interruptions of pipeline shipments to Egypt's customers in Israel and the Mashreq. Despite continued efforts by the weakened Egyptian government to improve the 
security of gas export infrastructure, and to resume gas deliveries, these incidents put enormous strain onto relations with Israel and Jordan. Both countries depend on Egyptian imports for 40 per cent and 80 per cent of their gas supply, respectively, and had to resort to more expensive fuel oil and diesel imports to satisfy the needs of the power sector.

The Egyptian authorities were rather unapologetic about these disruptions; they sought at the same time to increase the price of gas exports, leading to the realization in Israel and Jordan that the new regime in Egypt was not prepared to carry the political burden of the controversial gas export deals that the previous administration had concluded. As a result, all of Egypt's regional gas customers have began actively seeking alternative gas supply sources (Israel from its own offshore reserves and LNG imports; Jordan through LNG imports from Qatar; Syria/Lebanon from Iraq and possibly Iran through Turkey), making it easier for Egypt to eventually reduce pipeline exports significantly - if not do away with them altogether enabling it to focus on LNG sales and the domestic market.

The Libyan disruption. Besides sending small quantities of LNG (0.5-0.7 Bcm/yr) to Spain for the last 30 years, ${ }^{16}$ Libya started exporting gas to Italy through the $11 \mathrm{Bcm} / \mathrm{yr}$ Greenstream pipeline in 2004. Greenstream is part of the ENI-operated West Libya Gas Project (WLGP) and runs from Mellitah, west of Tripoli, to Gela in Sicily. It has been transporting 9-10 Bcm/yr of gas since 2005, accounting for some 12 per cent of Italy's gas imports.

Five days into the 17 February uprising, ENI - like all IOCs operating in Libya - decided to suspend most of its upstream activities in Libya, and shut down the Greenstream pipeline. ${ }^{17}$ Initially, the closure was said to be a temporary, precautionary measure, but the imposition of sanctions on the Gaddafi government by the UN and the EU subsequently undermined the prospect of reopening the pipeline before the end of the conflict. As a result, regardless of how long the closure eventually lasts, the Greenstream disruption had already, six months into the conflict, become the longest and most severe gas supply incident in the MENA region.

However, the impact of the loss of Libyan gas on the Italian and European markets has been minimal. Although ENI reported a 31 per cent drop in profits in the second quarter of 2011 
compared to a year earlier (as a result of the loss of its Libyan oil and gas output), it has been able to meet its customers' demand for gas without much difficulty. In fact, no sooner had the Greenstream closure taken place than government officials and market participants asserted that Italy was unlikely to suffer from shortages any time soon, given that the country had been oversupplied since 2009 - being unable to offtake minimum contracted volumes, particularly from Russia and Algeria (Table 3) - and retained plenty of gas in storage. ${ }^{18}$ This was confirmed by the behaviour of spot gas prices on the Italian over-the-counter market PSV following the Libyan disruption: it followed the general upward trend of spot gas prices on other north-west European traded hubs, which increased in the first quarter of 2011 mainly as a result of bullish oil prices and rising Asian LNG demand; and contrasts sharply with the behaviour of prices when the Transitgas line was shut down in July 2010 ${ }^{19}$ (Figures 19, 20).

Table 3: Italy's Take-or-Pay Performance, 2006-10

\begin{tabular}{|c|c|c|c|c|}
\hline \multirow{2}{*}{} & \multicolumn{4}{|c|}{ \% of Take-or-Pay taken } \\
\cline { 2 - 5 } & CY06/07 & CY07/08 & CY08/09 & CY09/10 \\
\hline Russia & 79 & 92 & 81 & 76 \\
\hline Algeria & 88 & 94 & 77 & 79 \\
\hline Libya & 127 & 142 & 143 & 129 \\
\hline Norway & 86 & 115 & 92 & 74 \\
\hline Netherlands & 109 & 121 & 102 & 85 \\
& & & & \\
\hline
\end{tabular}

Source: IEA (courtesy of Howard Rogers, OIES). 
Figure 19: European Spot Gas Prices February-March 2011 (\$/MMBtu)

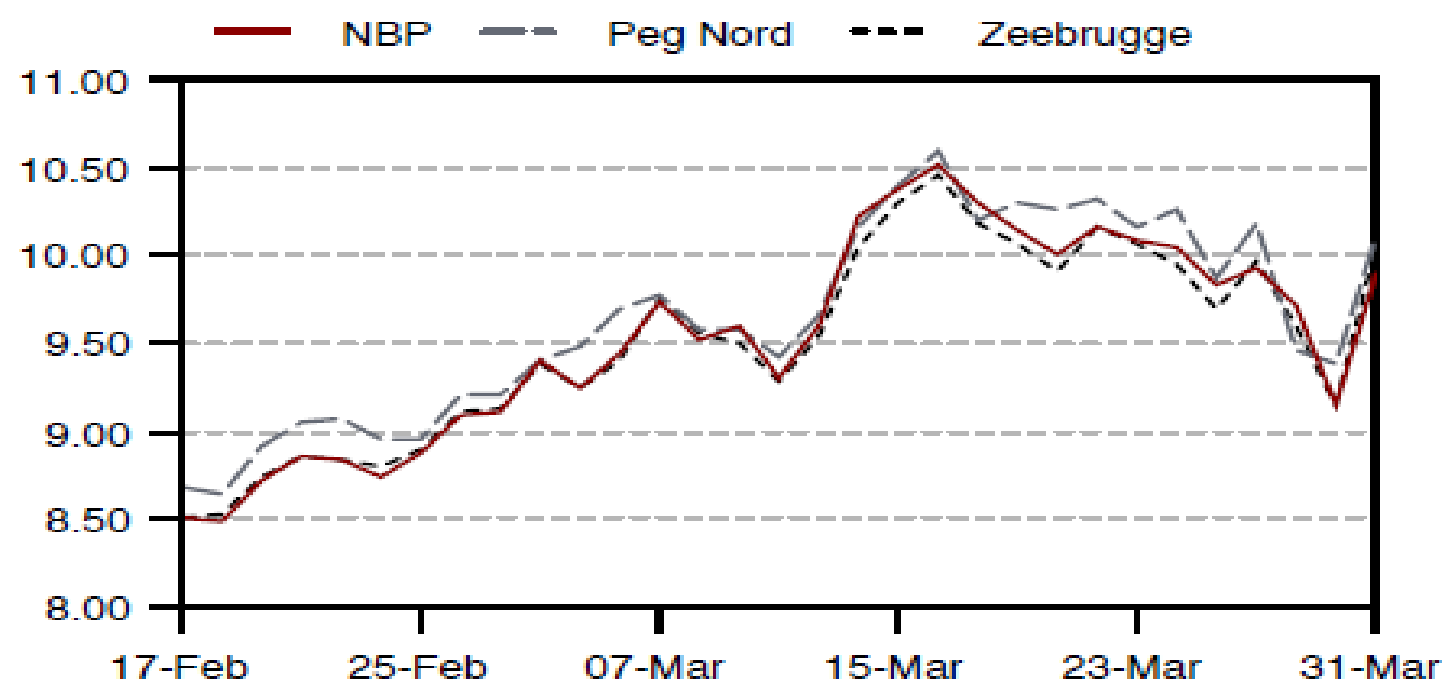

Source: Argus LNG Daily

Figure 20: Impact of the Transitgas and Greenstream Shutdowns on PSV Prices

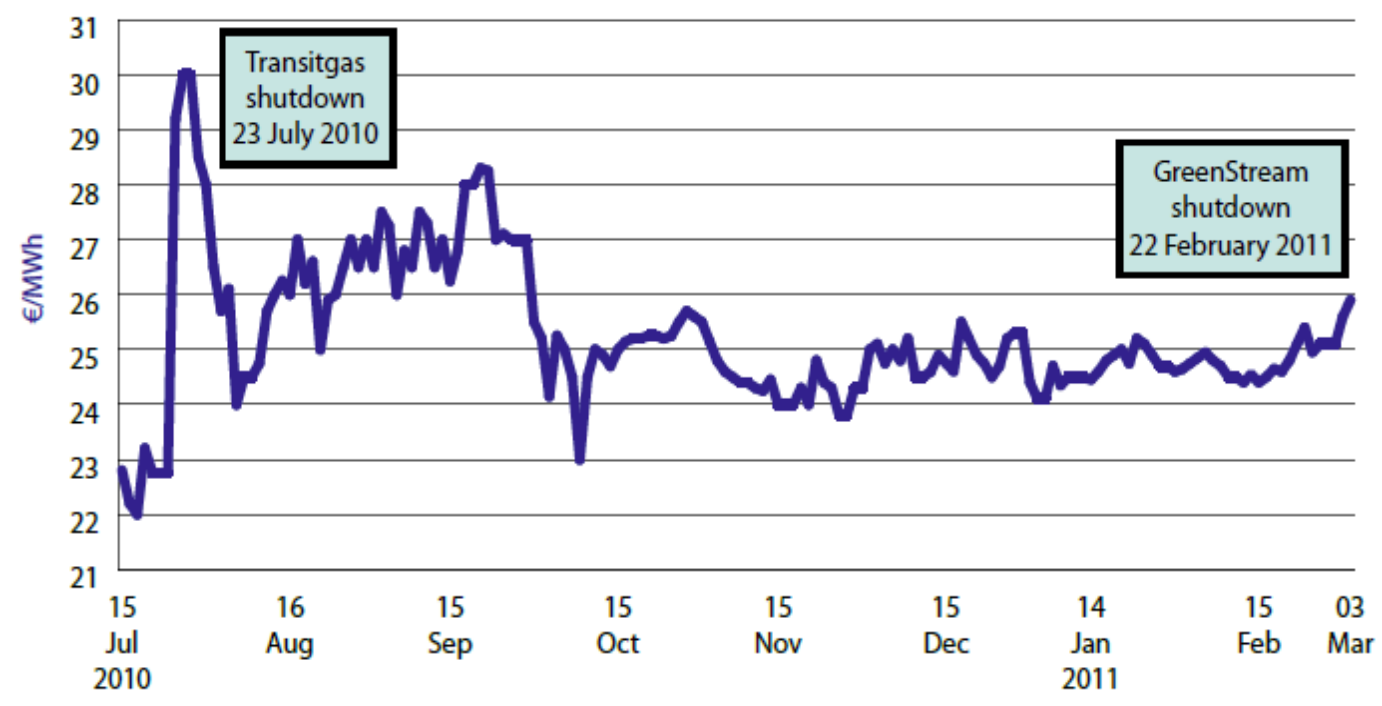

Source: ICIS Heren

In the light of the situation on the oversupplied Italian gas market, it was even suggested that ENI's decision on the suspension of Greenstream flows may have also been commercially motivated, as the move was seen as giving the Italian company the opportunity to balance the shortfall in Libyan supplies with the estimated $5 \mathrm{Bcm}$ of prepaid volumes from Russia's Gazprom, which ENI had been unable to take the previous year because of lower postrecession demand. ${ }^{20}$ Based on gas import data into Italy for the first half of 2011, it certainly 
appears that Russian gas supplies, which increased by over 50 per cent on the corresponding period in 2010, compensated for the outage of Libyan gas (Figure 21).

Figure 21: Italian Gas Imports by Source, First Half 2010 vs. First Half 2011
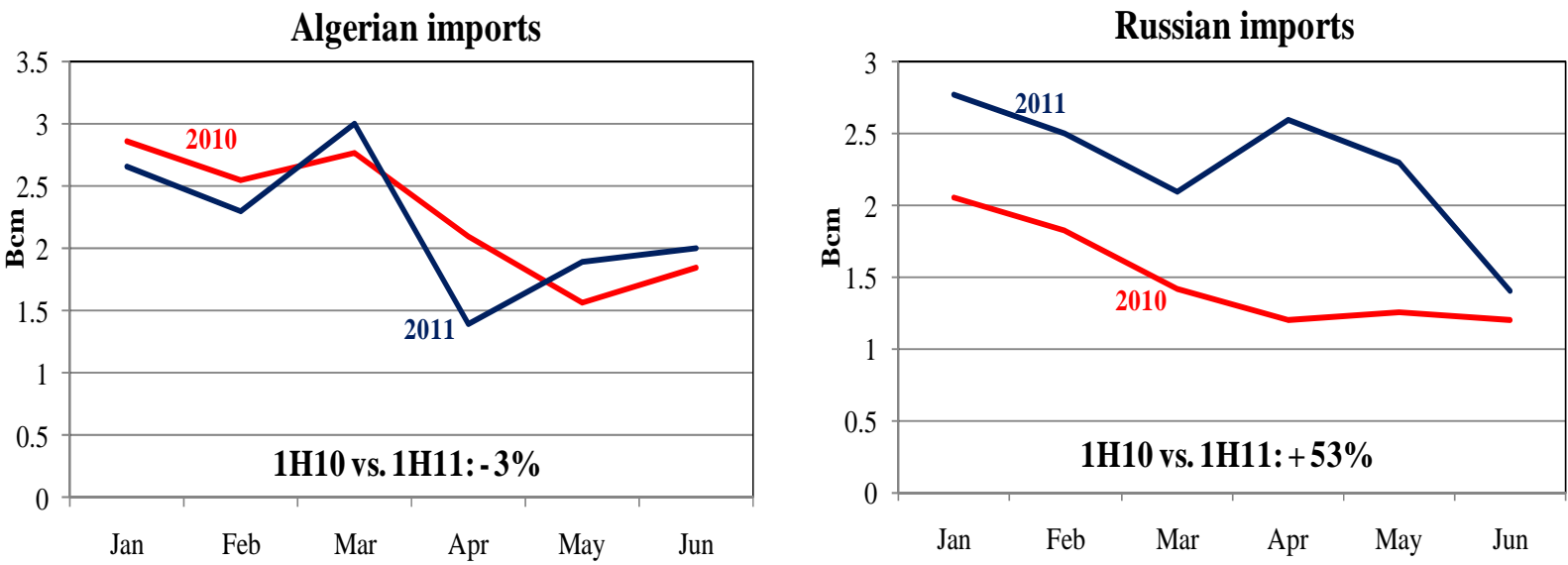

N. European imports

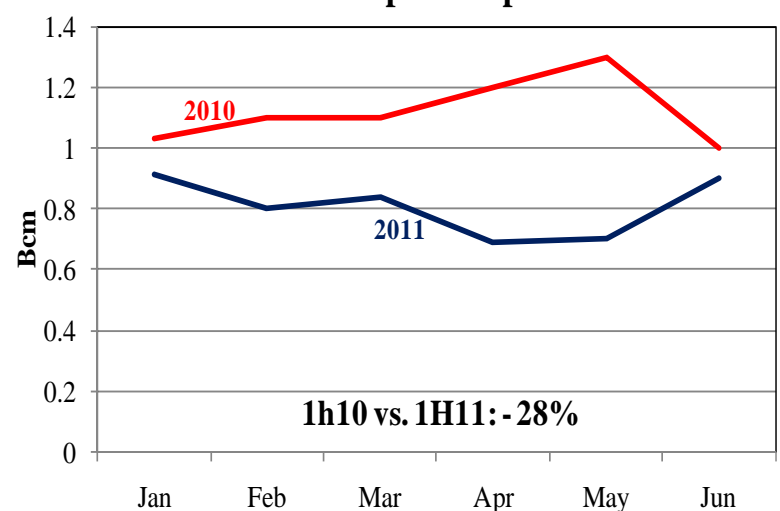

LNG imports
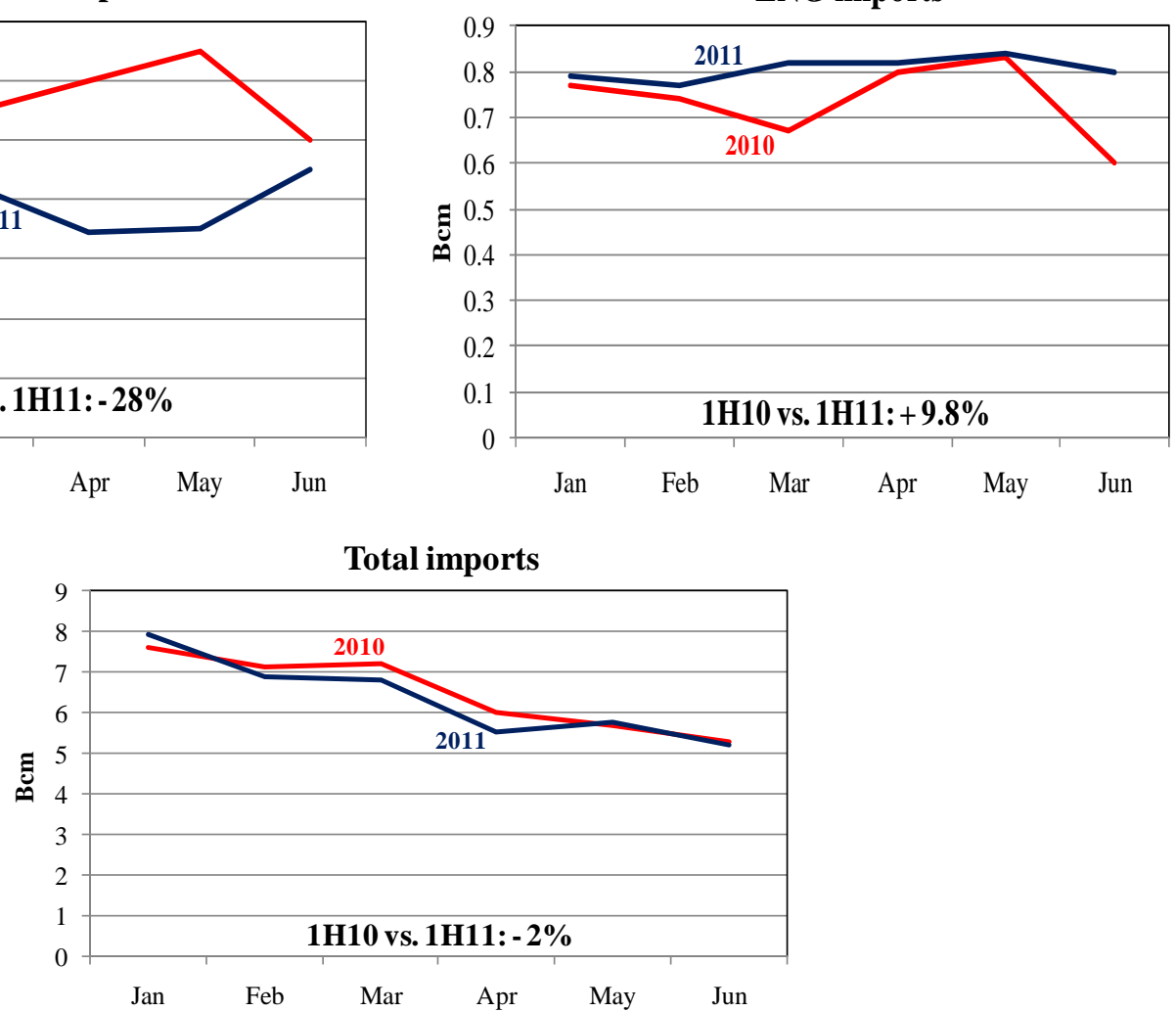

Source: Snam Rete Gas. 
Contagion fears. Although the Libyan gas supply disruption had a limited immediate effect on the Italian and European gas markets, the events that caused it exacerbated market fears about the spread of civil unrest to bigger MENA gas producers, particularly Algeria and Qatar. ${ }^{21}$ The latter, as mentioned above, plays a pivotal role in global LNG markets, while Algeria is Europe's third largest supplier of gas behind Russia and Norway, accounting for the biggest share in Italy's and Spain's gas imports. The prevailing feeling among observers of the region was that if uprisings could happen in Tunisia, Egypt, and Libya - the three countries believed prior to 2011 to be among the least likely to experience such events - they could well happen anywhere.

However, there was much less concern about Qatar, a country with the highest GDP (PPP) per capita in the world and little or no history of political instability, than about Algeria, which ranked higher on MENA political risk-assessment listings prior to the 2011 uprisings. Localized protests have been a permanent feature of the political background in Algeria for the best part of the last decade. The country has been in a state of 'stable instability' since the mid-1990s, having experienced a decade-long Islamist insurgency that was painfully defeated by the incumbent regime. The fact that an unprecedented wave of nationwide riots engulfed Algeria for four days in January, at the same time as the Tunisian uprising, caused many to believe it would be next, fearing the worst for the security of gas supplies to Europe.

Yet, eight months into the Arab uprisings, Algeria was among the few countries in the region to have witnessed limited or no protests calling for the removal of incumbent leaders, and many seasoned observers do not expect it 'to fall'. Having had their botched 'spring' more than 20 years ago, when in 1988 a youth-led uprising led to the introduction of sweeping but eventually costly - political and economic reforms, Algerians seem no longer interested in sudden, radical change. It is most certainly this shared aversion to political violence and further instability among large sections of the Algerian population that has militated against a repeat of the Tunisian and Egyptian experiences in Algeria. Algerians no doubt aspire to political change, but they are wary of the uncertainty associated with it, all the more so as most political and civil society actors in Algeria suffer from a debilitating lack of legitimacy, having consistently failed to live up to their mission of representation and democracy. 
Furthermore, the current Algerian regime does not exhibit a clear identifiable figure, embodied by the head of state, in the same way that Tunisia, Egypt, Libya, Syria, and Yemen did/do. Calling for the removal of President Abdelaziz Bouteflika (in power since 1999) has neither been called for nor perceived as practical, as his departure would be no panacea to the perverse influence on politics of the informal structures of power which Bouteflika is credited with having, to some extent, curbed. Indeed, Bouteflika is not nearly resented as much as his longer-serving counterparts in neighbouring countries were/are, and the idea of dynastic succession has not been strongly associated with him. Thus, despite sharing many of the prima facie conditions that led to the uprisings in other Arab countries, Algeria seems to be in many ways different, owing to its recent history and the nature of its political system. Having said this, the outlook for longer-term stability in the country remains uncertain, as does the final outcome for the region of the transformation process ushered in by recent events.

\section{Likely long-term implications for gas policy}

With recent events in the MENA region having, by and large, had a limited short-term impact on gas markets, questions remain concerning the implications of political change for gas development policies in the long term. Considering, as mentioned above, that 45 per cent of the world's proven gas reserves are located in MENA countries, any change of policy that affects the development of these resources and their monetization will inevitably have a longterm impact on global gas markets. The policy areas likely to be affected by political change are: domestic pricing (and other market) reforms; upstream investment terms and NOC-IOC relations; and export policies.

Domestic pricing reforms. The MENA region has some of the cheapest domestic gas prices in the world (Figure 22). These artificially-low downstream prices are the result of state regulation and are aimed at protecting the income of citizens, promoting economic diversification and access to modern forms of energy, and, particularly in resource-rich economies, are considered a way of distributing the rent as part of the 'social contract' underpinning state-society relations in these countries.

In addition to fiscal pressure, particularly for fiscally-short countries, these pricing policies cause numerous allocation and distributional distortions which, in relation to gas, tend to intensify the supply-demand gap by encouraging consumption patterns above the level 
warranted by their true opportunity cost and limiting potential supply responses. In the era of low-cost gas production - specifically gas associated with oil production and easily accessible, liquid-rich non-associated gas - regulated prices may have been less problematic. However, with booming gas consumption and rising upstream costs, these prices have become unsustainable in many MENA countries.

Figure 22: Average Wholesale Gas Prices by Region in 2009 (\$/MMBtu)

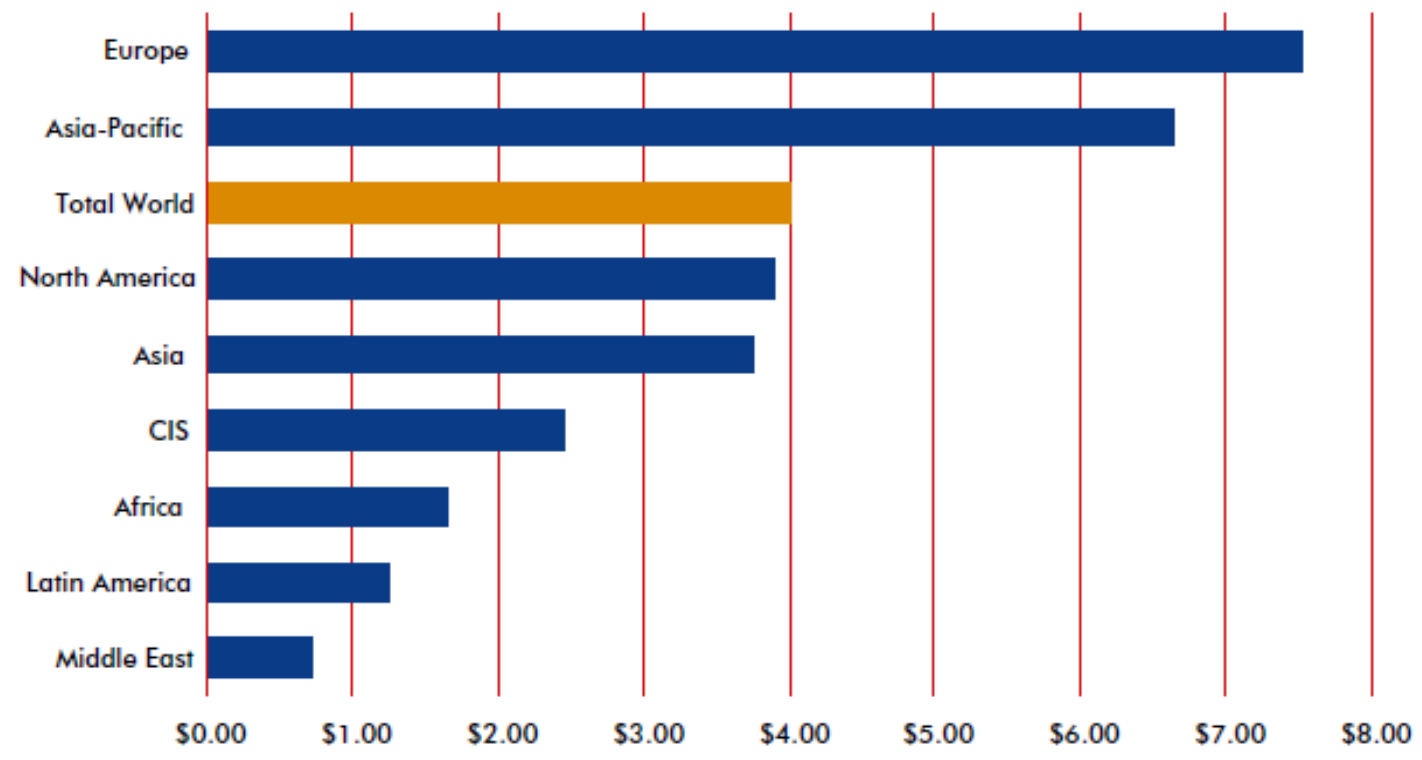

Source: Fulwood, M. (2011) 'Trends in Wholesale Gas Price Formation Mechanisms: Results of the 2009 IGU Survey', Nexant, London.

Prior to the uprisings, very few countries in the region had shown willingness to introduce reform to domestic gas and other energy-product prices. These pricing policies had become so embedded in the political economies of these countries that any effort to deal with them was seen as carrying the risk of raising daunting issues of economic competitiveness, macroeconomic management, and more importantly, socio-political stability. Only Iran, Egypt, and Saudi Arabia had openly recognized the extent of the problems caused by current pricing policies and attempted, to varying degrees, to introduce reforms. In December 2010, Iran introduced a comprehensive subsidy-reform plan which, in terms of gas, aims to raise prices for all users to 65-75 per cent of the export price index within five years. Egypt announced in 2008 that, within three years, it would increase gas prices for industrial users from \$1.25 to \$3/MMBtu. In addition, Saudi Arabia has for the last two to three years been contemplating at least doubling downstream gas prices from their current level of \$0.75/MMBtu. 
Following recent events in the region, MENA policymakers' longstanding reluctance to tackle the issue of low prices is likely be reinforced. Increased social pressure will, at least in the short term, force governments, old and new, to pursue populist policies with the aim of ensuring stability. ${ }^{22}$ This could mean, inter alia, that gas and other energy pricing reforms will be put on the backburner, particularly in hydrocarbon-rich countries. This seems to have already occurred in Saudi Arabia, where advanced plans to increase gas prices appear to have been put on hold; in Egypt, where gas subsidy expenditure has been expanded by more than 50 per cent in the fiscal year 2011-12, reaching over \$1.6 billion and accounting for more than 10 per cent of the overall energy subsidy bill; and in Algeria, where the government has pledged to maintain its $\$ 7$ billion yearly subsidy for the gas-and-power sector. As a result, Iran is now the only country in the MENA region implementing a domestic gas (and energy) pricing reform plan, and is doing so quite successfully, as the economy seems to be coping relatively well with the higher prices, and demand growth is expected to slow down.

The implications of the delays in pricing reforms for MENA gas markets will be, other things being equal, continued strong demand growth and increased constraints on supply. With the region becoming a major gas demand centre, less gas is likely to be available for export, and more countries could become gas importers. Against the background of tightening global markets until at least the middle of the current decade, these likely developments can be expected to have a tangible effect on international gas markets and prices.

Upstream investment terms and NOC-IOC relations. One of the main constraints on the MENA region's export capability (with the exception of Qatar) has been the lagged supply response to rising demand for gas. With the end of the era of low-cost gas production generally across the region, NOCs have had to increasingly tap into complex and more costly reserves (deep, tight, 'sour' gas, with estimated development costs of \$3-6/MMBtu) in order to meet their domestic requirements. As the development of these reserves normally requires the involvement of foreign expertise, the issue of whether existing petroleum laws and fiscal regimes provide the necessary incentive for foreign investment into the upstream gas sector, has become increasingly prominent.

The problem is that, in many MENA countries, considerations of national sovereignty have often prevented governments from offering attractive commercial terms for foreign investors. 
NOCs are given priority over IOCs in controlling the exploitation of resources, and maximizing revenues for the state. In addition to fiscal restrictions, international sanctions (such as those applied to Iran, Iraq, and Libya), low domestic pricing policies, and institutional inefficiency have been major impediments to investment in gas production. Normally, the more resources and technical expertise a state has, the more restrictions on foreign investment its upstream development policies tend to have. Interestingly, in the MENA region, it is in the countries that are newcomers to the gas (export) industry, notably Qatar, Oman, Egypt, and Yemen, that the involvement of foreign investors is most prominent, albeit for different reasons.

The drive to increase domestic gas supplies has led many MENA governments to recognize the need for improved and dedicated commercial terms for upstream gas development. However, until now very few have taken decisive action in this regard. In fact, there are concerns that as decision-makers become embroiled in attempts to satisfy the popular demands expressed in the recent uprisings and in fending off further unrest, issues such as gas upstream investment terms might slip off the agenda. Indirectly, even if this is limited to the short term, it is likely to have longer-term implications for gas supply, given the lead times involved in gas development projects.

More importantly, with governments across the region expanding their medium- to long-term public expenditure through increased public sector wages and social transfers, in the hope that this will quell popular agitation, ${ }^{23}$ it is likely that they will seek greater revenues from the oil and gas sector in order to meet these commitments. This drive to maximize the rent, in order to increase distribution of it, could reduce the ability of governments to offer more fiscal incentives for foreign investors, thus potentially limiting their involvement in upstream development. Anticipated higher oil prices will increase the likelihood of this possibility, as producers will be able to achieve greater revenues without necessarily having to ramp up output.

As foreign investors' perception of risk in the MENA region changes as a result of recent events, any tightening of fiscal terms will further deter investment in the upstream gas sector. This will be especially pertinent, as uncertainty in the region is not expected to wane anytime soon: countries that have seen their leaders removed from power will face the uncertainty of 
'what's next?' for years to come, with new power struggles likely to be dominated by Islamist and military forces; while the rest of the MENA countries will struggle to adapt to the changing 'social contract' and geopolitics in the region.

Against this backdrop, the all important relationship between NOCs and IOCs will hang in the balance, swinging in favour of the latter as MENA gas demand continues to grow unabated, and access to domestic supplies becomes all the more urgent, yet difficult. However, the emergence of more democratic political processes may lead to greater nationalist and populist policies, which besides favouring greater state control over national resources, may cause more protracted decision-making, both of which would bolster NOCs' influence.

Export policies. Notwithstanding the region's sizeable gas reserves, the outlook for MENA gas exports to 2020 is not particularly promising. ${ }^{24}$ The widening gap between rising demand and limited supply has not only led a number of gas producers in the region to curtail their export ambitions (Algeria, Oman, Iran, and Egypt), but it has also meant that several countries are facing gas shortages that can only be plugged by imports (the UAE, Kuwait, Bahrain, and Syria). Only Qatar and, to a lesser extent, Algeria are in a position to increase their gas exports within the next decade.

Iran could have more gas available for export, as a result of reduced demand growth, but it is uncertain whether those volumes will be exported by pipeline or used domestically for enhanced oil recovery. Iraq, too, should see gas production increase in the next few years, but most of that output will be needed domestically to feed much-needed new power generation plants and industries. There may be gas available for exports from the northern provinces of the country before 2020, but only in small quantities (up to 5-7 $\mathrm{Bcm} / \mathrm{yr}$ ). The recent discoveries in the eastern Mediterranean could prove to be a game-changer for the region's export prospects, but Israel - the country with the most advanced exploration programme thus far - faces a number of political, commercial, and policy challenges in the development of these resources before 2020 .

Besides the issues of domestic pricing and investment terms, which are likely to be affected by changes in the region, gas export policies are also unlikely to be spared by the ongoing 
transformations. There is little doubt that MENA governments will anxiously focus on creating jobs for young people, in the hope of allaying their socio-economic grievances. In gas-rich countries, these efforts will take the form of investment in energy-intensive industries using gas as feedstock. Policymakers in the region have invariably considered the availability of relatively cheap gas feedstock as a source of competitive advantage for their economies, allowing them to attract foreign investment, add value to their resources, and create job opportunities for unemployed young people.

Although many experts are sceptical about the viability of this strategy, the recent uprisings will only reinforce this approach. In Oman, for instance, where relatively small-scale protests took place early in 2011, the government promptly announced a \$10-15 billion 10-year investment programme in new petrochemical and infrastructure projects, with the aim of creating up to 20,000 jobs in the areas most affected by the protests. ${ }^{25}$ As a result, it can safely be expected that, instead of exporting their gas resources, some MENA governments will increasingly want to use them domestically to create jobs and improve living conditions. In other words, the recent events are likely to alter the gas monetization policies of some governments in the MENA region, leading to smaller volumes of gas being available for export than would otherwise have been the case. With the tightening of the supply-demand balance on global gas markets in the next few years, such developments have a strong potential - as with the issue of domestic prices and demand - of making a tangible effect on international market dynamics and prices.

\section{Conclusion - main messages}

This paper has examined both the short- and long-term effects of the Arab uprisings on global and regional oil and gas markets. In the short-term, the impact of ongoing political changes has manifested itself mainly in terms of greater market uncertainty and fears of contagion. Given that all of the spare oil production capacity and almost half of global LNG output originate in the MENA region, there was concern about unrest spreading to bigger regional producers.

However, for all the uncertainty ushered in by the Arab uprisings, a pattern has clearly emerged relating to the events that have taken place so far. The countries in the region that have experienced the most radical uprisings are those with nominal republican political 
systems and long-serving leaders (20 years and over) with a propensity to promote nepotism and dynastic succession, at the expense of inclusive economic development and broader participation in the political process. Clearly, Tunisia, Egypt, Libya, Yemen, and Syria fall within this category. It is no coincidence that the 'republics' of Algeria, Lebanon, and Iraq have seen little or no unrest; besides enjoying some degree of effective political pluralism, all three countries have suffered from domestic civil conflicts in the recent past. In other countries, the 'contagion effect' has demonstrated itself through the revival and emboldening of longstanding political demands for change, some of which are based on sectarian grievances, such as in Bahrain and to a lesser extent Saudi Arabia.

As it became clearer that the spread of unrest to key oil and gas producers like Saudi Arabia, Qatar, the UAE, Kuwait, and Algeria was unlikely, attention shifted to the potential longerterm implications of political change for oil and gas markets. The long-term risks that the Arab uprisings will engender are likely to be policy-related, with eventual implications for global oil and gas market dynamics. Our analysis highlights the following key aspects:

1. The resilience of oil and gas markets. International oil and gas markets have shown great resilience in dealing with the physical disruptions that have been caused by political unrest in the MENA region. Certainly, the events in the region contributed to higher oil, and indirectly gas, prices, and induced higher volatility, but the availability of spare oil production capacity, ample flexible LNG volumes in the system, and lower post-recession European gas demand provided a cushion against the impact of the Libyan outages in the short term.

2. MENA oil is different from MENA gas: MENA gas does not have the same geopolitical significance as MENA oil. Aside from the fact that oil and gas markets are intrinsically different (globalization, financialisation, end-use flexibility, etc.), the importance of MENA oil is global, while that of MENA gas is more regional. Historically, the security of oil supplies from the region has played a major role in shaping international relations between the 'West' and the Middle East, and has been a central tenet in the consumers' energy and foreign policies towards the region. Natural gas is unlikely to assume a similar position as oil; it is likely to play a secondary role in shaping MENA's relations with the rest of the world, perhaps with 
the exception of Qatar, which has succeeded in forging international and regional relations on the basis of its gas wealth.

In terms of implications for natural gas markets, our analysis suggests the following:

3. Domestic pricing reforms will be delayed: Much-needed downstream gas pricing reforms, particularly in hydrocarbon-rich MENA countries, are unlikely to take place anytime soon. Social pressure will force most governments to at least delay such reforms in order to fend off further unrest. This will mean that, all else being equal, gas consumption will continue growing solidly in these countries, limiting the amount of gas that will be available for exports. However, with the possible success of the Iranian five-year subsidy reduction programme which was started in late 2010, an example could be set for the rest of the MENA countries on how to deal with the pricing issue, even under pressure.

4. Gas monetization policies could shift away from exports: The growing pressure on MENA governments to create sufficient job opportunities for young people and to improve living conditions will, in some countries, lead to greater use of gas domestically both as feedstock for energy-intensive industries - such as petrochemicals - and where possible as fuel for power generation. In MENA countries where the domestic gas supply situation is already quite tight, this will lead to even smaller volumes of gas being available for export.

5. The outlook for MENA gas supply will be uncertain: In addition to the potential destructive impact of unrest on the long-term productive capacity of countries like Libya and the re-emergence of the risk premium associated with the region, the tightening, or lack of improvement, of upstream fiscal terms as a result of the changing priorities of old and new MENA governments in the aftermath of the uprisings might well severely limit investment opportunities and the prospects for expanded gas supply in the region. 
In terms of implications for global oil markets, the main messages are:

6. Current events in MENA will reinforce the dominant story in the oil market. The great uncertainty surrounding oil market dynamics in the aftermath of the financial crisis of 2008 did not prevent many market analysts from making bold predictions that market fundamentals were likely to tighten in the near future. Such predictions are based on three main pillars: (1) a very limited growth in non-OPEC supply due to peak oil and/or other constraints such as geopolitical factors and hardening fiscal terms on oil production; (2) a slowdown in investment in OPEC countries; and (3) a rapid growth in global oil demand fuelled mainly by non-OECD economies.

The recent events in MENA feed into the dominant story in five main ways. First, Libya's disruption has had the effect of speeding up the erosion of spare capacity. With the risk of outages remaining high in countries such as Syria and Yemen, there is a risk that the spare capacity will be eroded faster than the market originally anticipated. Second, there are concerns that recent events will reduce the ability of the MENA region to undertake the investment required to increase production in order to meet the projected increase in global demand, due to civil unrest, instability, sanctions, and diversion of funds towards social spending. Third, pricing reform, which is needed to slow down growth in domestic energy consumption, will become more difficult after the recent political shockwaves, eroding the export capability of MENA producers in the long term. Fourth, many governments in the region responded to the current events by ordering more handouts, and increasing government expenditure. This will increase the dependency of producers on high oil prices, increasing the floor price for key producers and inducing tighter market control, especially in a falling market. Finally, there is a perception that producer-consumer relations cannot be relied upon to smooth the oil market's adjustment to disruptions; indeed their actions could exacerbate price volatility.

A key question remains: What could change the underlying dynamics of the dominant story? As argued by Fattouh, ${ }^{26}$ the oil price can move within a wide band without necessarily inducing visible feedbacks of responses. If the market does not expect feedback on supply, demand, policy, or these responses are not visible, then the market will continue to test the upper bound and to put an upward pressure on oil prices. Currently, the only feedback that 
the market is attaching weight to is a slowdown in oil demand induced by expectations of a further slowdown in the global economy. The regular flow of information and mixed signals about the health of the global economy are likely to keep the oil price highly volatile within the current implicit price band of \$100-120 for Brent. The ongoing events in MENA will only amplify these short-term price movements, and in case of another disruption, they could push the price to a new band. Taking a long-term view, the year 2011 could prove to be a turning point, not only for the future evolution of oil market dynamics, but also for the way in which market players view their relations with each other, and the way they assess the potential risks and uncertainties currently engulfing the oil market. As market participants continue to shape their views and perceptions, and to revise some of the old assumptions about the oil market, the impact will be felt both on short-term and long-term price dynamics.

${ }^{1}$ IEA (2005). World Energy Outlook 2005: Middle East and North Africa Insights, Paris.

2 Hamilton, J.D. (2009) 'Causes and Consequences of the Oil Shock of 2007-2008', NBER Working Paper 15002, May.

${ }^{3}$ Martin, W.F., Imai, R., Steeg, H. (1996). Maintaining Energy Security in a Global Context, a Report to the Trilateral Commission, Trilateral Commission, June 1996.

${ }^{4}$ EIA (2011). World Oil Transit Chokepoints, February.

${ }^{5}$ Barclays Capital (2011). Oil Sketches: Mists of Time, March.

${ }^{6}$ Blas, J. (2011). 'Shockwaves from Saudi’s crude statistics', Financial Times, 19 April.

${ }^{7}$ Aït-Laoussine, N. and Gault,_J. (2011) 'Oil Price Reaction to Middle East Turmoil Is Unjustified And Dangerous', MEES, 4 March.

${ }^{8}$ Barclays Capital (2011), Oil Sketches: Spinning Around, 24 August.

${ }^{9}$ Saltmarsh, M. (2011) 'Energy Agency Calls for Rise in World Oil Output', New York Times, 19 May.

${ }^{10}$ MEES (2011), ‘OPEC Talks Collapse In 'Worst’ Meeting', VOL. LIV, No 24, 13 June

11 'IEA makes 60 million barrels of oil available to market to offset Libyan disruption', IEA Press Release, 23 June 2011.

${ }^{12}$ For more details on MENA gas supply and demand dynamics, see Fattouh, B. and Stern, J. (2011) Natural Gas Markets in the Middle East and North Africa, Oxford: OUP.

${ }^{13}$ For more details on these disruptions and the Iran-Turkey gas relationship see: Kinnander, E. (2010) 'The Turkish-Iranian Gas Relationship: Politically Successful, Commercially Problematic’, OIES, NG 38.

${ }^{14}$ See: Stern, J. (2007) 'Gas-OPEC: A Distraction from Important Issues of Russian Gas Supply to Europe', OIES; Darbouche, H. (2007) 'Russian-Algerian Cooperation and the “Gas-OPEC”: What’s in the Pipeline?’, CEPS Working Paper 123.

15 'With Transmed attack, Italy looks vulnerable', World Gas Intelligence, 27 July 2011.

${ }^{16}$ The LNG supply contract between Libya's NOC and Gas Natural Fenosa was due to expire in 2012.

${ }^{17}$ However, ENI has continued to supply the Libyan domestic market with 2-3 Bcm/yr from the WLGP.

18 'ENI sees Q2 earnings fall 31\% on Libya', European Gas Daily, 1 August 2011; 'Greenstream link suspended, but traders remaining calm’, European Gas Markets, 28 February 2011.

${ }^{19}$ Transitgas transports Norwegian and Dutch gas to Italy through Switzerland. It has a nameplate capacity of about $20 \mathrm{Bcm} / \mathrm{yr}$. It was closed between July and December 2010 because of damage caused by a landslide.

20 'Libya’s misfortunes benefit ENI and Gazprom', Gas Matters, March 2011.

${ }^{21}$ See for instance: Lochner, S. and Dieckhöner, C. (2010) 'Civil Unrest in North Africa: A Risk for Europe’s Natural Gas Supply? - A Scenario-based Analysis’, EWI, Cologne.

${ }^{22}$ There is also the possibility that more accountable democratic governments will be better able to pass unpopular, but necessary, legislation - such as on pricing reforms - but this is less likely, at least in the short term. 
${ }^{23}$ For instance, Saudi Arabia announced a package of almost $\$ 130$ billion in additional public spending for the next few years; Algeria increased its spending for 2011 alone by $\$ 25$ billion; Kuwait granted $\$ 4$ billion in cash handouts in addition to free food for all citizens for 14 months; Oman said it would spend an additional \$2.6 billion in 2011; Bahrain approved a \$2.7 billion public spending increase over the next 2 years; and both Oman and Bahrain are to receive $\$ 10$ billion each from the GCC in support of their spending needs.

${ }^{24}$ See Fattouh, B. and Stern, J. (2011).

25 'Oman to spend up to $\$ 15$ billion in projects', Gulf Today, 25 May 2011: http://gulftoday.ae/portal/1fa348b04422-411a-8b9c-0b99c53dac6d.aspx.

${ }^{26}$ Fattouh, B. (2010) 'Oil Market Dynamics through the Lens of the 2002-2009 Price Cycle’, OIES, WPM 39. 